\title{
Antioxidant, DNA cleavage, and cellular effects of silibinin and a new oxovanadium(IV)/silibinin complex
}

\author{
Luciana G. Naso • Evelina G. Ferrer • Nataliya Butenko • Isabel Cavaco • \\ Luis Lezama $\cdot$ Teófilo Rojo $\cdot$ Susana B. Etcheverry $\cdot$ Patricia A. M. Williams
}

Received: 16 November 2010/ Accepted: 27 February 2011/Published online: 12 March 2011

(C) SBIC 2011

\begin{abstract}
A new complex of the oxovanadium(IV) cation with the flavolignan silibinin has been synthesized and characterized. Vanadium compounds show interesting biological and pharmacological properties and some of them display antitumoral actions. Flavonoids are part of a larger group of antioxidant compounds called polyphenols which may inhibit the proliferation and growth of cancer cells. The antioxidant and antitumoral effects of silibinin and its oxovanadium(IV) complex were investigated. Silibinin acted as a very strong antioxidant and its complexation with oxovanadium(IV) improved this behavior. Besides, the generation of reactive oxygen species (ROS) by this compound was favored in tumoral (UMR106) cells and correlated with the deleterious behavior in the proliferation of this cell line.
\end{abstract}

Electronic supplementary material The online version of this article (doi:10.1007/s00775-011-0769-8) contains supplementary material, which is available to authorized users.

L. G. Naso · E. G. Ferrer · S. B. Etcheverry ·

P. A. M. Williams $(\bowtie)$

Centro de Química Inorgánica (CEQUINOR/CONICET,

UNLP), Facultad de Ciencias Exactas,

Universidad Nacional de La Plata,

47 y 115, 1900 La Plata, Argentina

e-mail: williams@quimica.unlp.edu.ar

N. Butenko

Departamento de Química,

Bioquímica e Farmácia, Universidade do Algarve,

Campus de Gambelas,

8005-139 Faro, Portugal

N. Butenko - I. Cavaco

Centro de Química Estrutural,

Instituto Superior Técnico,

TU Lisbon, Av Rovisco Pais,

1049-001 Lisbon, Portugal
Conversely, silibinin did not exert any effect on the proliferation of normal osteoblasts (MC3T3E1). The cytotoxic action and ROS generation of the oxovanadium(IV) complex was more effective in tumoral cells. This behavior was not consistent with cleaving DNA of plasmid DNA pA1 because no significant cleaving activity was observed in both cases. These results suggest that the main deleterious mechanisms may take place through cytotoxic effects more than genotoxic actions. A comparison with our own findings on the behavior of other flavonoids and their vanadyl(IV) complex has also been performed.

Keywords Oxovanadium(IV) - Silibinin · Osteoblasts · Antioxidant · Antitumoral 


\begin{tabular}{|c|c|}
\hline \multicolumn{2}{|c|}{ Abbreviations } \\
\hline AAPH & $\begin{array}{l}\text { 2,2'-Azobis(2-methylpropionamidine) } \\
\text { dihydrochloride }\end{array}$ \\
\hline ABTS & $\begin{array}{l}\text { 2,2'-Azinobis(3-ethyl-benzothiazoline-6- } \\
\text { sulfonic acid) diammonium salt }\end{array}$ \\
\hline AGE & Agarose gel electrophoresi \\
\hline bp & Base pair \\
\hline DHR & Dihydrorhodamine \\
\hline DMEM & Dulbecco's modified Eagle's medium \\
\hline DMSO & Dimethyl sulfoxide \\
\hline $\mathrm{DPPH}^{-}$ & 1,1-Diphenyl-2-picrylhydrazyl \\
\hline EDTA & Ethylenediaminetetraacetic acid \\
\hline FBS & Fetal bovine serum \\
\hline FTIR & Fourier transform infrared \\
\hline MOPS & 3-(N-Morpholino)propanesulfonic acid \\
\hline MPA & Mercaptopropionic acid \\
\hline NADH & Reduced nicotinamide adenine dinucleotide \\
\hline NBT & Nitroblue tetrazolium \\
\hline ORAC & Oxygen radical absorbance capacity \\
\hline PBS & Phosphate-buffered saline \\
\hline ROS & Reactive oxygen species \\
\hline SOD & Superoxide dismutase \\
\hline TEAC & Trolox-equivalent antioxidant coefficient \\
\hline VOsil & $\left.\mathrm{Na}_{2}[\mathrm{VO} \text { (silibinin })_{2}\right] \cdot 6 \mathrm{H}_{2} \mathrm{O}$ \\
\hline
\end{tabular}

\section{Introduction}

Silibinin, or silybin (3,5,7-trihydroxy-2-[3-(S)-(4-hydroxy3-methoxyphenyl)-2-(S)-(hydroxymethyl)-2,3-dihydro-1,4benzodioxin-6-yl]chroman-4-one) (Fig. 1), is the major active constituent of silymarin, extracted form blessed milk thistle. Its extract is used in medicine under the name silymarin (a mixture of flavonolignans silibinin A, silibinin B, isosibilinin A, isosibilinin B, silicristin, and silidianin). It is used in cases of liver diseases because of its hepatoprotective, antioxidant properties which preserve the membrane lipids of the hepatocytes [1-3].

Silibinin has also demonstrated potent antiproliferative effects against various malignant cell lines [1] such as human prostate adenocarcinoma $[4,5]$, human breast and<smiles>COc1cc(C2Oc3cc(C4Oc5cc(O)cc(O)c5C(=O)[C@H]4O)ccc3OC2CO)ccc1O</smiles>

Fig. 1 Structure of silibinin cervical carcinoma [6], and human colon cancer cells [7]. Besides, a comparison of the cancer chemopreventive and anticarcinogenic effects of silymarin and silibinin concluded that the effects of silymarin are due to its major component silibinin [7]. Silibinin has low water solubility and its bioavailability was achieved by preparation of the complex silybin- $\beta$-cyclodextrin [8] for oral administration or its succinate salt (Legalon) [9] for intravenous infusion.

To enrich the knowledge base of antioxidant lignoflavonoids, rational design and preparation of silibinin derivatives were performed [10]. The effect of metal complexation parallels the organic modification of these radical scavenger compounds.

The oxovanadium(IV) cation is a biometal with important biological properties, and several vanadium compounds show potential pharmacological activity mainly as insulin mimics and antitumoral and osteogenic agents. Vanadium compounds have been considered as a new class of metal-based antitumor agents in recent decades and are assumed to be reactive oxygen species (ROS)-generating agents [11]. Because of this behavior, the potential antitumoral action of novel vanadium complexes having different coordination spheres has been determined [12]. As part of a project devoted to establishing the antioxidant and antitumoral properties of flavonoids and the improvement or not of their behavior when they are coordinated to a vanadium metal center, we have synthesized a new compound of silibinin and vanadyl(IV) cation. The complex was characterized by means of elemental analysis, UV-vis, EPR, and Fourier transform infrared (FTIR) spectroscopies, and thermal degradation analysis. Its antioxidant properties were determined. The antiproliferative effects against normal (MC3T3E1) and tumoral (UMR106) osteoblasts were also measured and contrasted with the effects of ROS generated in the cultures. Reversibility and morphological studies were also performed. Antioxidant effects and cellular proliferation were compared with previous data obtained for flavonoid- $-\mathrm{V}^{\mathrm{IV}} \mathrm{O}(\mathrm{II})$ complexes.

\section{Materials and methods}

Silibinin (Sigma), oxovanadium(IV) chloride (50\% aqueous solution, Carlo Erba), and oxovanadium(IV) sulfate pentahydrate (Merck) were used as supplied. Corning or Falcon provided tissue culture materials. Dulbecco's modified Eagle's medium (DMEM), and trypsin-ethylenediaminetetraacetic acid (EDTA) were purchased from Gibco (Gaithersburg, MD, USA), and fetal bovine serum (FBS) was from GibcoBRL (Life Technologies, Germany). All other chemicals used were of analytical grade. Elemental analysis for carbon and hydrogen was performed using a Carlo Erba EA1108 analyzer. Vanadium content was determined by the 
tungstophosphovanadic method [13] and sodium content was determined by flame photometry. Thermogravimetric analysis and differential thermal analysis were performed with Shimadzu systems (models TG-50 and DTA-50, respectively), working in an oxygen flow of $50 \mathrm{~mL} / \mathrm{min}$ and at a heating rate of $10{ }^{\circ} \mathrm{C} / \mathrm{min}$. Sample quantities ranged between 10 and $20 \mathrm{mg}$. $\mathrm{Al}_{2} \mathrm{O}_{3}$ was used as a differential thermal analysis standard. UV-vis spectra determinations were recorded with a Hewlett-Packard 8453 diode-array spectrophotometer. The diffuse reflectance spectrum was recorded with a Shimadzu UV-300 spectrophotometer, using $\mathrm{MgO}$ as a standard. Infrared spectra were recorded with a Bruker IFS 66 FTIR spectrophotometer from 4,000 to $400 \mathrm{~cm}^{-1}$ using the $\mathrm{KBr}$ pellet technique. A Bruker ESP300 spectrometer operating at the X-band and equipped with standard Oxford Instruments low-temperature devices (ESR900/ITC4) was used to record the spectrum of the complex at room temperature in the solid state. A computer simulation of the EPR spectra was performed using the program WINEPR SimFonia (version 1.25, Bruker Analytische Messtecnik, 1996). Fluorescence spectra were obtained using a PerkinElmer (Beaconsfield, UK) LS-50B luminescence spectrometer equipped with a pulsed xenon lamp (half peak height less than $10 \mu \mathrm{s}, 60 \mathrm{~Hz}$ ), an R928 photomultiplier tube, and a computer working with FL Winlab.

\section{Preparation of $\mathrm{Na}_{2}\left[\mathrm{VO}(\text { silibinin })_{2}\right] \cdot 6 \mathrm{H}_{2} \mathrm{O}$}

$\mathrm{VOCl}_{2}(50 \%$ aqueous solution, $0.125 \mathrm{mmol})$ was added to an ethanolic solution $(10 \mathrm{~mL})$ of silibinin $(0.25 \mathrm{mmol})$. The solution was heated slightly and stirred for $1 \mathrm{~h}$, and the $\mathrm{pH}$ was adjusted to 9 by addition of a solution of $\mathrm{NaOCH}_{3}$. The warm suspension was filtered and the green powder of $\mathrm{Na}_{2}$ [VO(silibinin) $\left.)_{2}\right] \cdot 6 \mathrm{H}_{2} \mathrm{O}$ (VOsil)was washed with absolute ethanol and dried in an oven at $60^{\circ} \mathrm{C}$. Anal. calcd. for $\mathrm{C}_{50} \mathrm{H}_{52} \mathrm{O}_{27} \mathrm{VNa}_{2}$ : C 50.8, H 4.4, V 4.3, Na 3.9. Found: C 50.0, $\mathrm{H} 4.4, \mathrm{~V} \mathrm{4.3,} \mathrm{Na} \mathrm{4.0 \% .} \mathrm{Thermogravimetric} \mathrm{analysis}$ (oxygen atmosphere, velocity, $50 \mathrm{~mL} / \mathrm{min}$ ): In a first step $\left(30-110^{\circ} \mathrm{C}\right)$ the six water molecules are lost $(9.1 \%$ calcd., $9.2 \%$ exp.). The dehydrated product $\mathrm{Na}_{2}$ [VO(silibinin) $\left.)_{2}\right]$ rendered $\mathrm{NaVO}_{3}$ (characterized by infrared spectroscopy) and $\mathrm{Na}_{2} \mathrm{O}$ at $800{ }^{\circ} \mathrm{C}$. The weight of the final residue was $12.8 \%$, in agreement with the theoretical value. UV-vis spectrum (dimethyl sulfoxide, DMSO): $560 \mathrm{~nm} \mathrm{(sh),}$ $765 \mathrm{~nm}\left(\varepsilon=90 \mathrm{M}^{-1} \mathrm{~cm}^{-1}\right)$. Diffuse reflectance spectrum: $640 \mathrm{~nm}$, above $800 \mathrm{~nm}$.

Antioxidant properties

\section{1,1-Diphenyl-2-picrylhydrazyl assay}

The antiradical activity of silibinin and $\mathrm{Na}_{2}[\mathrm{VO}$ (silibi$\left.\operatorname{nin})_{2}\right] \cdot 6 \mathrm{H}_{2} \mathrm{O}$ (VOsil) was measured in triplicate using a modified Yamaguchi et al. [14] method. A methanolic solution of 1,1-diphenyl-2-picrylhydrazyl (DPPH) radical (4 mL, $40 \mathrm{ppm}$ ) was added to $1 \mathrm{~mL}$ of the antioxidant solutions in $0.1 \mathrm{M}$ tris(hydroxymethyl)aminomethane- $\mathrm{HCl}$ buffer ( $\mathrm{pH} \mathrm{7.1)}$ at $25^{\circ} \mathrm{C}$, giving final concentrations of 10 , 25,50 , and $100 \mu \mathrm{M}$. From the UV-vis spectra, the absorbance at $517 \mathrm{~nm}$ was measured after $60 \mathrm{~min}$ of the reaction in the dark and compared with the absorbance of a control prepared in a similar way without the addition of the antioxidants (this value was assigned arbitrarily as 100).

\section{2,2'-Azinobis(3-ethylbenzothiazoline-6-sulfonic acid) diammonium salt decoloration assay}

The total antioxidant activity was measured using the Trolox (6-hydroxy-2,5,7,8-tetramethylchroman-2-carboxylic acid)equivalent antioxidant coefficient (TEAC). The radical cation of 2,2'-azinobis(3-ethylbenzothiazoline-6-sulfonic acid) diammonium salt (ABTS) was generated by incubating ABTS with potassium persulfate. Chemical compounds that inhibit the potassium persulfate activity may reduce the production of $\mathrm{ABTS}^{+}$. This reduction resulted in a decrease of the total $\mathrm{ABTS}^{+}$concentration in the system and contributed to the total ABTS ${ }^{+}$scavenging capacity. Briefly, an aqueous solution of ABTS $(0.25 \mathrm{mM})$ and potassium persulfate $(0.04 \mathrm{mM})$ was incubated in the dark for $24 \mathrm{~h}$. The solution was then diluted 5 times in $0.1 \mathrm{M} \mathrm{KH}_{2} \mathrm{PO}_{4}-\mathrm{NaOH}$ buffer (pH 7.4). To $990 \mu \mathrm{L}$ of this mixture, $10 \mu \mathrm{L}$ of silibinin, the complex, or the Trolox standard in a phosphate buffer was added (final concentrations $0-100 \mu \mathrm{M}$ ). The reduction of ABTS $^{+}$was monitored spectrophotometrically 6 min after the initial mixing at $25{ }^{\circ} \mathrm{C}$. The percentage decrease of the absorbance of the band at $734 \mathrm{~nm}$ was calculated considering that the basal condition (without antioxidant additions) had been assigned as $100 \%$ and it was plotted as a function of the concentration of the samples giving the total antioxidant activity. The TEAC was calculated from the slope of the plot of the percentage inhibition of absorbance versus the concentration of the antioxidant divided by the slope of the plot for Trolox [15, 16].

\section{Superoxide dismutase assay}

The superoxide dismutase (SOD) activity was examined indirectly using the nitroblue tetrazolium (NBT) assay. The indirect determination of the activity of silibinin and the vanadium complex was assayed by their ability to inhibit the reduction of NBT by the superoxide anion generated by the phenazine methosulfate and the reduced nicotinamide adenine dinucleotide (NADH) system. As the reaction proceeded, the formazan color developed and we observed a change from yellow to blue associated with an increase of the intensity of the band at $560 \mathrm{~nm}$ in the absorption spectrum. 
The system contained $0.5 \mathrm{~mL}$ of sample, $0.5 \mathrm{~mL}$ of $1.40 \mathrm{mM}$ $\mathrm{NADH}$, and $0.5 \mathrm{~mL}$ of $300 \mu \mathrm{M} \mathrm{NBT}$, in $0.1 \mathrm{M} \mathrm{KH}_{2} \mathrm{PO}_{4-}$ $\mathrm{NaOH}$ buffer ( $\mathrm{pH} 7.5$ ). After incubation at $25^{\circ} \mathrm{C}$ for $15 \mathrm{~min}$, the reaction was started by adding $0.5 \mathrm{~mL}$ of $120 \mu \mathrm{M}$ phenazine methosulfate [15]. Then, the reaction mixture was incubated for $5 \mathrm{~min}$. Each experiment was performed in triplicate and at least three independent experiments were performed in each case. The amount of complex (or silibinin) that gave $50 \%$ inhibition $\left(\mathrm{IC}_{50}\right)$ was obtained by plotting the percentage of inhibition versus the logarithm of the concentration of the solution tested.

\section{Scavenging power of the hydroxyl radical}

Hydroxyl radicals were generated by the ascorbate/iron/ $\mathrm{H}_{2} \mathrm{O}_{2}$ system. Briefly, the reaction mixture contained $3.75 \mathrm{mM}$ 2-deoxyribose, $2.0 \mathrm{mM} \mathrm{H} \mathrm{H}_{2} \mathrm{O}_{2}, 100 \mu \mathrm{M} \mathrm{FeCl}_{3}$, and $100 \mu \mathrm{M}$ EDTA without or with the test compound in $20 \mathrm{mM} \mathrm{KH} \mathrm{PO}_{4}-\mathrm{KOH}$ buffer, $\mathrm{pH}$ 7.4. The reaction was triggered by the addition of $100 \mu \mathrm{M}$ ascorbate and the mixture was incubated at $37{ }^{\circ} \mathrm{C}$ for $30 \mathrm{~min}$. Solutions of $\mathrm{FeCl}_{3}$, ascorbate, and $\mathrm{H}_{2} \mathrm{O}_{2}$ were made up in deaerated water immediately before use. The extent of deoxyribose degradation by hydroxyl radical was measured with the thiobarbituric acid method $[17,18]$.

\section{The oxygen radical absorbance capacity assay}

This assay is based on the capacity of antioxidants to quench peroxyl radicals that are generated from the thermal decomposition of 2,2'-azobis(2-methylpropionamidine) dihydrochloride (AAPH) $\left(30 \mathrm{~min}, 37^{\circ} \mathrm{C}\right)$ [19-21]. A stock solution of fluorescein was prepared by taking $44 \mathrm{mg}$ of fluorescein, dissolving it in $100 \mathrm{~mL}$ of phosphate buffer (75 mM, pH 7.0), and then storing the solution in complete darkness under refrigeration conditions. The working solution $(78 \mathrm{nM})$ was prepared daily by dilution of $0.167 \mathrm{~mL}$ of the stock solution in $25 \mathrm{~mL}$ of phosphate buffer. The AAPH radical $(300 \mathrm{mM})$ was prepared daily. As the oxygen radical absorbance capacity (ORAC) assay is extremely sensitive, the samples must be diluted appropriately before analysis to avoid interference. To the reaction mixture containing $1,000 \mu \mathrm{L}$ of fluorescein $(78 \mathrm{nM})$ and 1,000 $\mu \mathrm{L}$ of sample, blank (phosphate buffer), or standard (Trolox), $500 \mu \mathrm{L}$ of AAPH $(300 \mathrm{mM})$ was added. The cell was thermostatted at $37^{\circ} \mathrm{C}$. Fluorescence was read every minute for an excitation wavelength of $488 \mathrm{~nm}$ and an emission wavelength of $512 \mathrm{~nm}$.

DNA cleavage activity of VOsil measured by agarose gel electrophoresis of plasmid DNA

The plasmid DNA used for gel electrophoresis experiments was pA1, which consists of a full-length complementary DNA from cytochrome P450 CYP3A1 inserted in the PBS plasmid vector (pBluescribe, Stratagene, UK) and is described elsewhere [22]. Plasmid DNA was amplified in Escherichia coli DH5a and purified using a PureYield ${ }^{\mathrm{TM}}$ plasmid midiprep system from Promega. Linear DNA was obtained by digestion of pA1 with HindIII and used as a reference in agarose gel electrophoresis (AGE). A sample digested with $50 \mu \mathrm{M} \mathrm{VO}(\mathrm{acac})_{2}$, where acac is acetylacetonate, was also sometimes used as a reference for the linear form of DNA. DNA concentration per nucleotide base pair (bp) was determined by UV absorption at $260 \mathrm{~nm}$ using the extinction coefficient of $13,200 \mathrm{M}^{-1} \mathrm{~cm}^{-1} \mathrm{bp}^{-1}$. A $200 \mu \mathrm{M}$ mother solution of vanadium complex in deionized Milli-Q water was freshly prepared for each experiment. The stability of the aqueous solution was followed by UV spectroscopy and it was found that in 15 min there were no spectral changes (data not shown). DNA cleavage activity was evaluated by monitoring the conversion of supercoiled plasmid DNA to nicked circular DNA, and linear DNA. Each reaction mixture was prepared by adding (in this order) $6 \mu \mathrm{L}$ of water, $2 \mu \mathrm{L}$ $(0.2 \mu \mathrm{g})$ of supercoiled pA1 DNA, $2 \mu \mathrm{L}$ of $100 \mathrm{mM}$ stock $\mathrm{pH} 7$ buffer solution, and $10 \mu \mathrm{L}$ of the aqueous solution of the complex. The $\mathrm{pH}$ buffer was 3 - $(\mathrm{N}$-morpholino)propanesulfonic acid (MOPS) $/ \mathrm{NaOH}$ and $\mathrm{PO}_{4}{ }^{3-}$ (phosphate) $/ \mathrm{HNO}_{3}$. The final reaction volume was $20 \mu \mathrm{L}$ and the final metal concentrations tested were $6,12,25$, 50, and $100 \mu \mathrm{M}$, which correspond to metal-to-DNA (bp) ratios of $0.2,0.4,0.8,1.7$, and 3.3. Unlike the ligand, which is scarcely soluble in water, $\mathrm{VO}($ sil) dissolved easily. The final buffer concentration was $10 \mathrm{mM}$. When the reaction involved additional activating agents, the initial volume of water was reduced to $4 \mu \mathrm{L}$, and $2 \mu \mathrm{L}$ of a solution of the agent was added before the metal complex. Mercaptopropionic acid (MPA) and oxone $\left(\mathrm{KHSO}_{5}\right)$ were chosen as reducing and oxidizing activating agents, respectively. Their final concentration was $200 \mu \mathrm{M}$. Control samples of activating agents were prepared in the absence of the metal complex. Samples of $\mathrm{VOSO}_{4} \cdot 5 \mathrm{H}_{2} \mathrm{O}$ with and without activating agents were also prepared for comparison.

Samples were typically incubated for $1 \mathrm{~h}$ at $37^{\circ} \mathrm{C}$, wrapped up in aluminum foil. After incubation, $5 \mu \mathrm{L}$ of DNA loading buffer $(0.25 \%$ bromophenol blue, $0.25 \%$ xylene cyanol, $30 \%$ glycerol in water) was added to each tube and the solution was loaded onto a $1 \%$ agarose gel in a buffer of $89 \mathrm{mM}$ Tris-borate and $1 \mathrm{mM}$ EDTA, pH 8.3, containing ethidium bromide $(1 \mu \mathrm{g} / \mathrm{mL})$. Controls of nonincubated and of linearized plasmid were included in both extremes of a 16-well gel plate. The electrophoresis was carried out for $3 \mathrm{~h}$ at $100 \mathrm{~V}$. Bands were visualized under UV light and photographed using an AlphaImager (Alpha Innotech). 
Cell culture

MC3T3E1 osteoblastic mouse calvaria-derived cells and UMR106 rat osteosarcoma-derived cells were grown in DMEM supplemented with $100 \mathrm{U} / \mathrm{mL}$ penicillin, $100 \mu \mathrm{g} /$ $\mathrm{mL}$ streptomycin, and $10 \%(\mathrm{v} / \mathrm{v}) \mathrm{FBS}$ at $37{ }^{\circ} \mathrm{C}, 5 \% \mathrm{CO}_{2}$. When $70-80 \%$ confluence was reached, cells were subcultured using $0.1 \%$ trypsin, $1 \mathrm{mM}$ EDTA in $\mathrm{Ca}$ (II)$\mathrm{Mg}(\mathrm{II})$-free phosphate-buffered saline (PBS) (11 mM $\mathrm{KH}_{2} \mathrm{PO}_{4}, 26 \mathrm{mM} \mathrm{Na}_{2} \mathrm{HPO}_{4}, 115 \mathrm{mM} \mathrm{NaCl}, \mathrm{pH}$ 7.4). For experiments, the cells were grown in multiwell plates. When the cells reached $70 \%$ confluence, the monolayers were washed twice with DMEM and were incubated in different conditions depending on the experiments.

\section{Biological assays}

Cell proliferation, reversibility assay, and cell morphology experiments were performed with $\mathrm{V}^{\mathrm{IV}} \mathrm{O}(\mathrm{II})$, the complex, and the free ligand. Intracellular formation of ROS was also determined. Briefly, the cell proliferation was assessed by the crystal violet bioassay. Stock complex solutions were prepared by dissolving VOsil in DMSO with a manipulation time of $5 \mathrm{~min}$. Then, the solution of the complex was immediately diluted with DMEM. The maximum concentration of DMSO in DMEM was always lower than $0.5 \%$, being innocuous for the cultures. Then, the complex solution was added to the cells in different concentrations and the cells were incubated for $24 \mathrm{~h}$. The stability of the complex in DMSO solution was followed by UV-vis spectroscopy. The complex remains stable in a DMSO solution (no changes were observed in the UV-vis spectra) for at least $30 \mathrm{~min}$ (the manipulation time for biological studies was $15 \mathrm{~min}$ ). The cells in culture were fixed with 5\% glutaraldehyde/PBS at room temperature for $10 \mathrm{~min}$. Then, they were stained with crystal violet after the incubation period. Next, they were washed to remove the excess of dye. The crystal violet taken up by the osteoblasts was extracted with the appropriate buffer and the absorbance was measured at $540 \mathrm{~nm}$. Previously, a linear correlation had been established for the number of cells and the absorbance [23].

The intracellular ROS generation in osteoblast-like cells was measured by oxidation of dihydrorhodamine (DHR) to rhodamine. Osteoblast-like cells were incubated for $30 \mathrm{~min}$ at $37^{\circ} \mathrm{C}$ in $1.5 \mathrm{~mL}$ of Hank's buffered salt solution alone (basal condition) or with silibinin, VOsil, and $\mathrm{V}^{\mathrm{IV}} \mathrm{O}(\mathrm{II})$, in the presence of $10 \mathrm{mM}$ DHR [24]. The media were separated and the cell monolayers were rinsed with PBS and lysed into $1 \mathrm{~mL}$ of $0.1 \%$ Triton-X 100 . The cell extracts were then analyzed for the oxidized product rhodamine by measuring the fluorescence spectra (excitation wavelength $500 \mathrm{~nm}$, emission wavelength $536 \mathrm{~nm}$ ). The results were corrected for protein content, which was assessed by the method of Bradford [25].

The reversibility studies were performed to establish if the deleterious effect of VOsil was reversible. Briefly, the cells were incubated with increasing concentrations of the complex for $24 \mathrm{~h}$ at $37^{\circ} \mathrm{C}$. Then, half of the wells were used to evaluate cell proliferation by the crystal violet assay. The other 24 wells were washed to eliminate the conditioned medium with the complex and were then incubated with DMEM supplemented with FBS. The osteoblasts were cultured for another $24 \mathrm{~h}$ under this condition to determine the potential recovery of cell viability by the crystal violet assay.

To evaluate the morphology of the cells, they were grown in six-well plates and incubated overnight with fresh serum-free DMEM plus $0 \mu \mathrm{M}$ (basal), $50 \mu \mathrm{M}$, and $100 \mu \mathrm{M}$ solutions of the complex. The monolayers were subsequently washed twice with PBS, fixed with methanol, and stained with 1:10 dilution of Giemsa stain for $10 \mathrm{~min}$ [26]. Next, they were washed with water and the morphological changes were examined by light microscopy.

At least three independent experiments were performed for each experimental condition in all the biological assays. The results are expressed as the mean \pm the standard error of the mean. Statistical differences were analyzed using the analysis of variance method followed by the test of least significant difference (Fisher).

\section{Results and discussion}

\section{FTIR spectra}

When flavonoids coordinate to metal centers, the carbonyl stretching frequency decreases and this is clear indication that metal coordination involves this group together with the $\mathrm{OH}$ groups in the 3-position or the 5-position [27-30].

In the infrared spectrum of silibinin, the band associated with carbonyl group vibration at $1,635 \mathrm{~cm}^{-1}$ and the absorption bands at $1,598,1,511$, and $1,465 \mathrm{~cm}^{-1}$ related to carbon vibration in benzene, lignan [31], and pyrone rings $(\mathrm{C}=\mathrm{C}$ vibrations) appeared.

The main FTIR bands with tentative assignments are listed in Table 1. By comparing the spectrum of the ligand with that of the complex, we can obtain important information. A shift of the carbonyl group $(\mathrm{C}=\mathrm{O})$ vibration from 1,635 to $1,611 \mathrm{~cm}^{-1}$ for the complex was observed when this group interacted with oxovanadium(IV). The frequency of the band associated with the $v(\mathrm{C}-\mathrm{O}-\mathrm{C})$ stretching vibration mode changed slightly upon complexation, indicating that the ring oxygen of the ligand did not form metal-oxygen bonds with the metal ion. However, the frequencies of the bands of the ligand associated 
Table 1 Assignment of the main bands of the infrared spectra of silibinin and its oxovanadium(IV) complex $\left.\mathrm{Na}_{2}[\mathrm{VO} \text { (silibinin) })_{2}\right] \cdot 6 \mathrm{H}_{2} \mathrm{O}$ (VOsil) (band positions in reciprocal centimeters)

$v s$ very strong, $s$ strong, $m$ medium, $w$ weak, $s h$ shoulder, $\delta_{i p}$ in-plane bending

\begin{tabular}{lll}
\hline Silibinin & VOsil & Assignments \\
\hline $3,459 \mathrm{~s}$ & $3,398 \mathrm{~m}$ & $v$ OH \\
$2,943 \mathrm{~m}$ & $2,955 \mathrm{sh}, 2,926 \mathrm{w}$ & $v-\mathrm{OCH}{ }$ \\
$1,635 \mathrm{vs}$ & $1,637 \mathrm{sh}, 1,611 \mathrm{~s}$ & $v \mathrm{C}=\mathrm{O}$ \\
$1,598 \mathrm{sh}$ & $1,556 \mathrm{~m}$ & $\delta(\mathrm{OH})$ \\
$1,511 \mathrm{~s}$ & $1,505 \mathrm{~s}$ & $v$ phenyl ring \\
$1,465 \mathrm{~s}$ & $1,467 \mathrm{~m}$ & $v$ phenyl ring, $\delta(\mathrm{OH})$ \\
$1,438 \mathrm{~m}$ & $1,439 \mathrm{sh}$ & $\delta(\mathrm{CH}$ arom $)$ \\
$1,366 \mathrm{~s}$ & $1,373 \mathrm{~m}$ & Ring A, C trigonal str, $\delta(3-\mathrm{OH}), \delta(5-\mathrm{OH})$, \\
$1,281 \mathrm{~s}$ & $1,309 \mathrm{sh}, 1,275 \mathrm{vs}$ & $v \mathrm{COC}$ \\
$1,240 \mathrm{sh}$ & $1,214 \mathrm{sh}$ & $\delta(3-\mathrm{OH}), \delta(5-\mathrm{OH})$ \\
$1,188 \mathrm{sh}$ & $1,177 \mathrm{~m}$ & $v \mathrm{CO}$ \\
$1,164 \mathrm{~s}$ & $1,162 \mathrm{sh}$ & Ring B,$\delta_{\text {ip }}(\mathrm{CH})$ \\
$1,130 \mathrm{~m}$ & $1,126 \mathrm{~m}$ & $v \mathrm{CO}, \delta(\mathrm{CH}$ arom $)$ \\
$1,082 \mathrm{~m}$ & $1,089 \mathrm{~m}$ & $\delta_{\text {ip }}(\mathrm{COC}), \delta_{\text {ip }}(\mathrm{CH}) ; v \mathrm{CO}$ secondary alcohol \\
$1,029 \mathrm{~m}$ & $1,030 \mathrm{w}$ & $v \mathrm{CO}$ primary alcohol \\
& $945 \mathrm{~m}$ & $v \mathrm{~V}=\mathrm{O}$ \\
\hline
\end{tabular}

with $\delta(3-\mathrm{OH})$ and $\delta(5-\mathrm{OH})$ vibrational modes shifted and the intensities were also reduced, suggesting that the coordination of the oxovanadium(IV) ion with the silibinin ligand most probably took place via carbonyl oxygen and $\mathrm{OH}$ groups $(3-\mathrm{OH}$ or $5-\mathrm{OH})$ of the ligand after deprotonation to form the metal-oxygen bonds in the complexes. Besides, it is well known that secondary alcohols deprotonate at higher $\mathrm{pH}$ values than primary alcohols. In addition, the weak intensity of the $\mathrm{C}-\mathrm{O}$ stretching band associated with primary alcohol $\left(1,029 \mathrm{~cm}^{-1}\right.$, medium intensity) pointed to the deprotonation of this group at $\mathrm{pH} 9$ when silibinin coordinated to the vanadium center. Then, it could be concluded that each ligand acquired a double negative charge and the complex precipitated as a sodium salt, to neutralize the anionic complex obtained. Moreover, the position of the $v(\mathrm{~V}=\mathrm{O})$ stretching band $\left(945 \mathrm{~cm}^{-1}\right)$ agreed with the presence of an oxygenated coordination sphere around the metal center [27].

\section{EPR spectroscopy}

The EPR spectrum of the solid complex was measured at room temperature: an eight-line hyperfine splitting pattern due to the unpaired electron of the ${ }^{51} \mathrm{~V}$ nucleus $(I=7 / 2)$ was obtained, indicating that only one mononuclear oxovanadium(IV) species predominates in VOsil. With use of the calculated parameters, the experimental spectrum was simulated and the fitting was in good concordance with the experimental spectrum (Fig. 2).

The simulation predicted that the new observed signal originated from a vanadium chromophore, being consistent with the oxovanadium(IV) ion in a nearly axial or pseudoaxial ligand field. The spin Hamiltonian parameters were

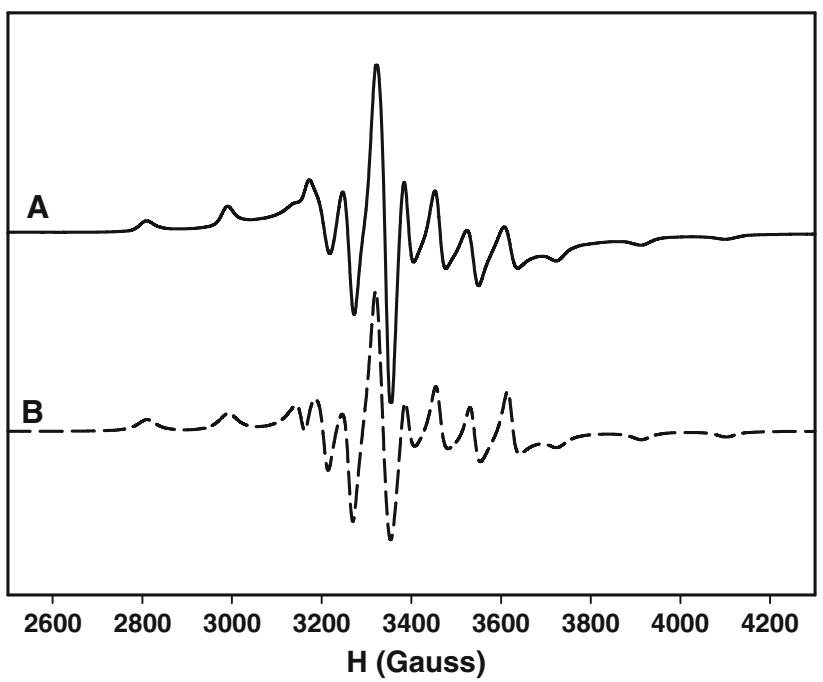

Fig. 2 Experimental $(A)$ and calculated (B) room-temperature powder EPR spectra of $\left.\mathrm{Na}_{2}[\mathrm{VO} \text { (silibinin) })_{2}\right] \cdot 6 \mathrm{H}_{2} \mathrm{O}$ (VOsil) measured at X-band $(9.742 \mathrm{GHz})$

$g_{\|}=1.942$ and $g_{\perp}=1.976$ and the hyperfine coupling constants were $A_{\|}=167.5 \times 10^{-4} \mathrm{~cm}^{-1}$ and $A_{\perp}=61 \times$ $10^{-4} \mathrm{~cm}^{-1}\left(g_{\text {iso }}=1.965, A_{\text {iso }}=96.5 \times 10^{-4} \mathrm{~cm}^{-1}\right)$. An additivity relationship introduced by Chasteen [32] has frequently been used to determine the identity of the equatorial ligands in V(IV) complexes: $A_{z}=\Sigma n_{i} A_{z, i}\left(n_{i}\right.$ is the number of equatorial ligands of type $i ; A_{z, i}$ is the contribution to the parallel hyperfine coupling from each of them). The hyperfine coupling constant, $A$, was correlated with the number and types of ligands present in the equatorial plane. Each donor group had a specific contribution to this constant and the sum of the contributions of the four equatorial ligands can be compared with the observed value. The calculated $A$ value 
for the donor sets in a possible equatorial coordination in the complex was $166.6 \times 10^{-4} \mathrm{~cm}^{-1}$ (two $\mathrm{C}=\mathrm{O}$, two $\mathrm{ArO}^{-}$). This value was calculated considering the following literature values for the contribution of each donor group to $A$ : $\mathrm{ArO}^{-} 38.6 \times 10^{-4} \mathrm{~cm}^{-1}$ and $\mathrm{C}=\mathrm{O} 44.7 \times 10^{-4} \mathrm{~cm}^{-1}$ [33]. The calculated $A$ value corresponded well with the experimental value, indicating in the present case that the binding mode of this complex could be expected to involve an equatorial coordination sphere with two oxygen atoms from $\mathrm{C}=\mathrm{O}$ groups and two deprotonated $\mathrm{ArO}^{-}$(from the flavonoid moiety of the ligand) bound to the oxovanadium(IV) center, giving the well known trans-VOL 2 structure in maltol-type compounds.

\section{Solution studies}

\section{$U V$-vis spectra}

To study the interaction of silibinin and $\mathrm{V}^{\mathrm{IV}} \mathrm{O}$ (II) cation in solution, we analyzed the UV spectra of the ligand at different $\mathrm{pH}$ values. The reported UV spectral pattern of silibinin in methanolic solution versus $\mathrm{pH}$ showed three titration steps [29], with protonation constants $\mathrm{p} K 10.03$, 13.30, and 13.67. In another report, the dissociation constants of silibinin measured using the SQUAD regression analysis program applied to $\mathrm{pH}$-spectrophotometric titration data were determined in water, at $25^{\circ} \mathrm{C}$, to be 7.00 , $8.77,9.57$, and 11.66 [34]. The UV spectra of silibinin at different $\mathrm{pH}$ values depicted in Fig. 3 were measured in ethanolic solutions (the solvent used in the synthesis of the complex).

It can be seen that the ligand began to deprotonate at $\mathrm{pH} \approx 6$ and the spectral pattern was maintained to

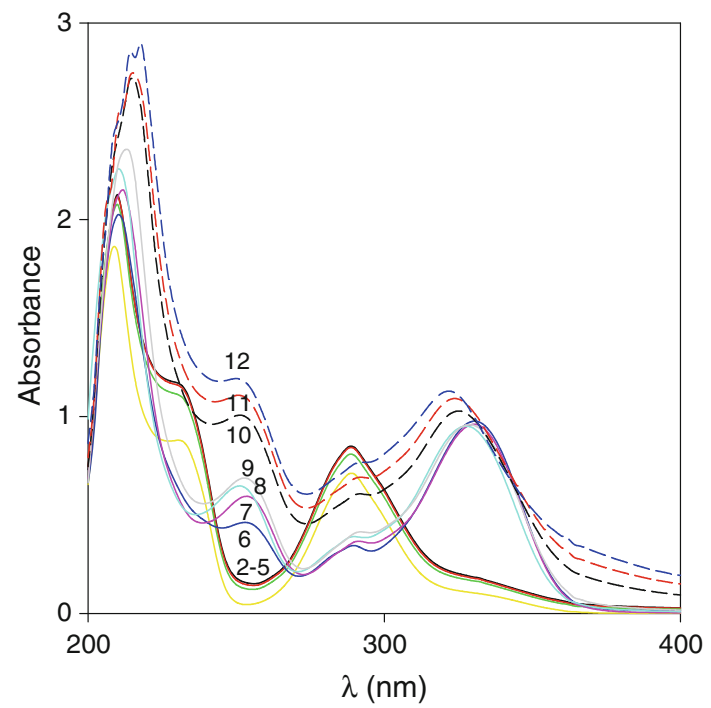

Fig. 3 Spectra of silibinin $\left(4 \times 10^{-5} \mathrm{M}\right)$, ethanolic solutions, for different $\mathrm{pH}$ values, nitrogen atmosphere
$\mathrm{pH} \approx 9$, where it changed again (the $\mathrm{pH}$ values were measured directly in ethanolic solutions and the solvent effect was not taken into account).

The interaction of the ligand with $\mathrm{V}^{\mathrm{IV}} \mathrm{O}$ (II) cation was investigated by measuring the variation of the electronic spectra of ethanolic solutions of silibinin/VO, in a $2: 1$ ligand-to-metal ratio, at different $\mathrm{pH}$ values (Fig. 4).

It can be seen that the intensity of the band at $328 \mathrm{~nm}$ began to increase at $\mathrm{pH}$ above 8 , indicating that the interaction of the metal with the ligand started at this stage. Therefore, the $\mathrm{pH}$ value selected for the synthesis of the $\mathrm{V}^{\mathrm{IV}} \mathrm{O}$ (II) silibinin complex was fixed to 9. The spectrophotometric titration measurements were then performed under these experimental conditions and at pH 9 (Fig. 5). A 2:1 ligand-to-metal stoichiometry was determined.

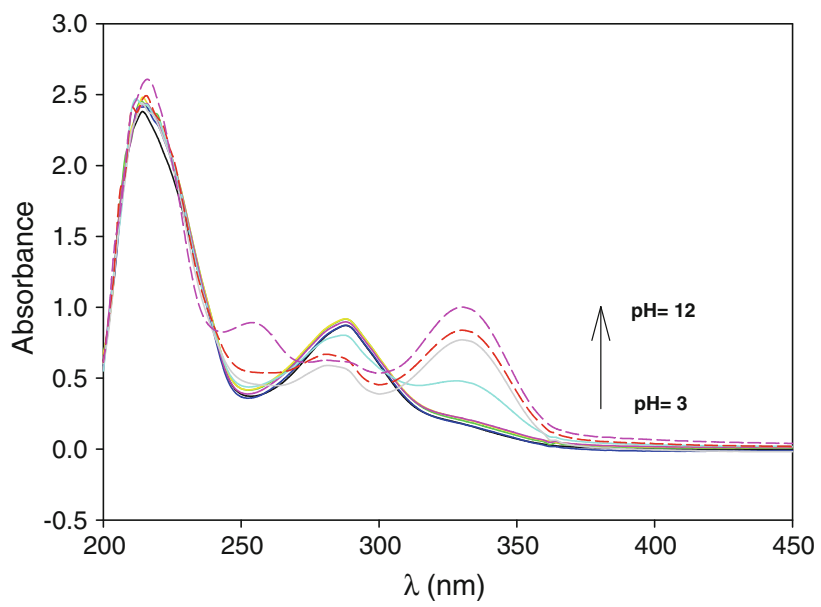

Fig. 4 Spectra of $\operatorname{VOCl}_{2}\left(2 \times 10^{-5} \mathrm{M}\right)$ and silibinin $\left(4 \times 10^{-5} \mathrm{M}\right)$, ethanolic solutions, for different $\mathrm{pH}$ values

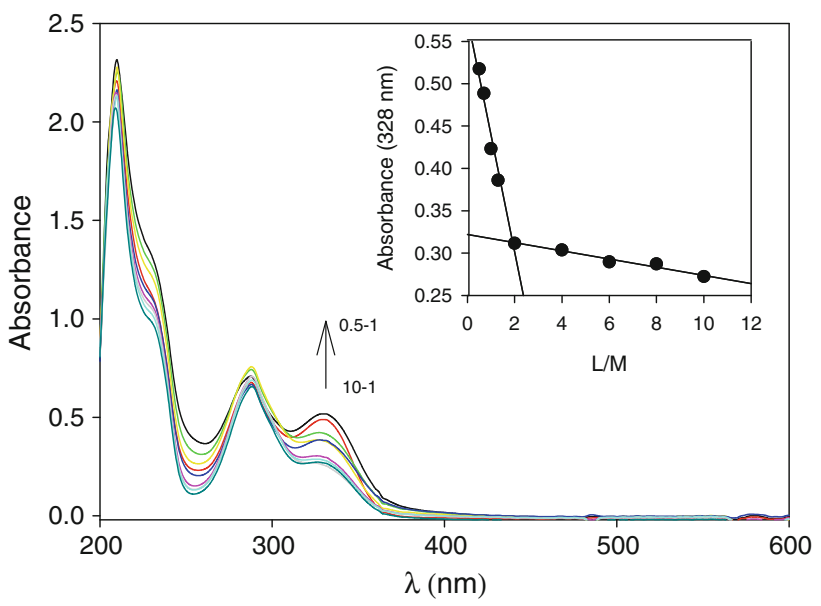

Fig. $5 \mathrm{UV}$-vis spectra of silibinin $\left(4 \times 10^{-5} \mathrm{M}\right)$ and $\mathrm{VOCl}_{2}$ in ligand-to-metal ratios $(L / M)$ from 10.0 to 0.5 ( $\mathrm{pH} 9)$, nitrogen atmosphere. The arrow indicates increasing metal additions. Inset Spectrophotometric determination of the stoichiometry of the VOsil complex at $328 \mathrm{~nm}$ by the molar ratio method 
When the coordination of the metal to the flavonoid occurred through the carbonyl group and the $3-\mathrm{OH}$ deprotonated hydroxyl, a new band located at approximately $430 \mathrm{~nm}$ was generally observed [35]. This interaction generated an electronic redistribution between the ligand and the metal forming a big extended $\pi$-bond system. The $n-\pi^{*}$ electronic transition belonging to the flavonoid changed to $\pi-\pi^{*}$ with lower energy, favoring the development of a new band at higher wavelength (redshift) [36]. In contrast, the electronic spectrum of VOsil is different, indicating that in this case the metal possibly interacts with the ligand through the $\mathrm{C}=\mathrm{O}$ group and the 5-OH deprotonated hydroxyl group.

\section{Antioxidant properties}

There is consensus that free radical reactions are relevant in many normal and pathological processes of living cells and those that flavonoids are an important class of defense antioxidants. The radical scavenger activities of silibinin were determined to be in accord with other flavonoids activities. These activities were greatly improved in VOsil.

The determination of the superoxide scavenger behavior of the ligand showed that the concentration of silibinin that produced $50 \%$ inhibition of the SOD activity was $3.16 \mu \mathrm{M}$ (see Fig. 6). This value was lower than other values reported previously, but different sources of superoxide radical generation were used in the latter determinations (55 $\mu \mathrm{M}[34]$ and $35 \%$ of inhibition at $50 \mu \mathrm{M}$ concentration [10]). Nevertheless, it was not possible to directly compare the experimental results on the capacity to scavenge superoxide radical using different methods of generation of

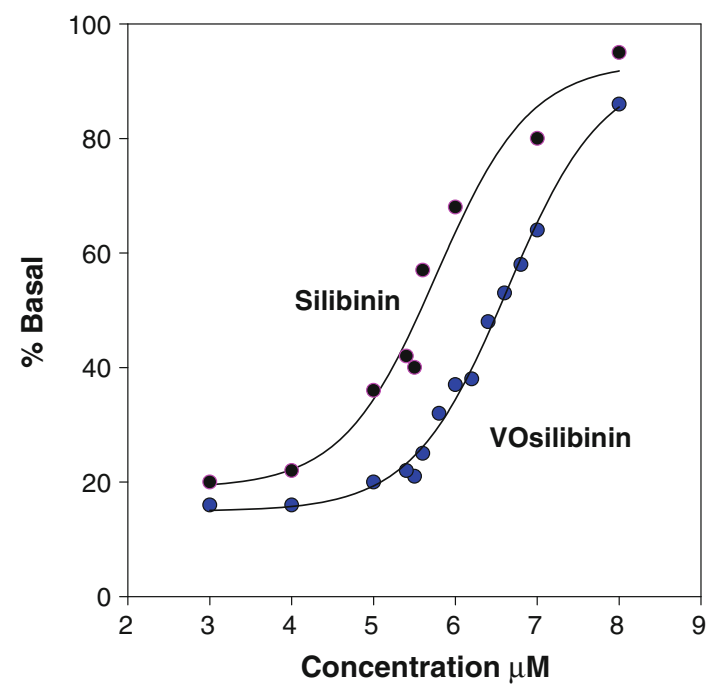

Fig. 6 Effects of silibinin and VOsil on the reduction of nitroblue tetrazolium by nonenzymatically generated superoxide (phenazine methosulfate and reduced nicotinamide adenine dinucleotide system) the radical [37]. However, it can be seen that the antioxidant behavior of VOsil was enhanced upon coordination $\left(\mathrm{IC}_{50}=0.26 \mu \mathrm{M}\right)$.

Bleaching of DPPH free radicals is another assay to evaluate the scavenging potential of stable free radicals in vitro. Previous results indicated that silibinin exerted $20 \%$ inhibition with respect to quercetin at a concentration of $50 \mu \mathrm{M}[10,38]: \mathrm{IC}_{50}>1,000 \mu \mathrm{M}$ or $\mathrm{IC}_{50}=1,745 \mu \mathrm{M}$ [36]. Our own data referred to a total basal inhibition of DPPH at $100 \mu \mathrm{M}$ of $16 \%$, in accordance with previous results (see Fig. 7). Surprisingly, the improvement of this antioxidant property upon complexation with oxovanadium(IV) cation enhanced the value 5 times, up to $83 \%$ inhibition.

The assay for the total antioxidant activity measures the concentration of an antioxidant compound that suppresses the absorbance of $\mathrm{ABTS}^{+}$at $734 \mathrm{~nm}$ (basal conditions). The TEAC measures the ratio of the slopes of the percentage of the basal level versus the concentration of the scavenger related to the Trolox (water-soluble analogue or vitamin E) slope. The total antioxidant activity and TEAC values obtained for both silibinin and VOsil were similar (Fig. 8), and showed that these compounds behaved as good ABTS scavengers.

However, one of the best antioxidant flavonoids, quercetin, had a TEAC value of 4.7, 2.6 times higher than that of silibinin and that of its oxovanadium(IV) complex. Taking into account that silibinin is the major active

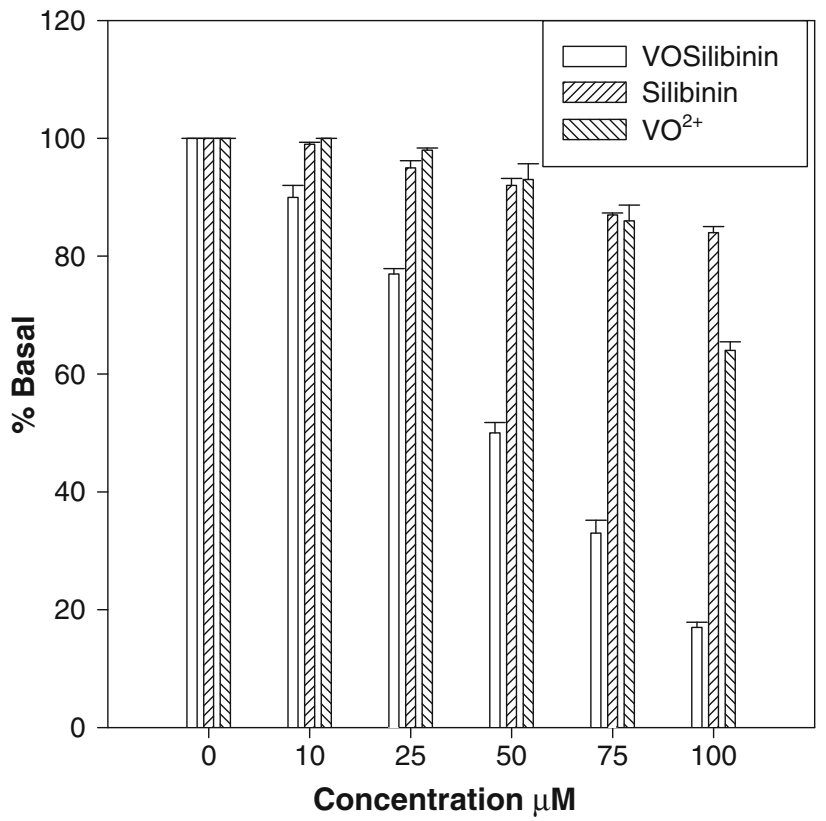

Fig. 7 Effects of silibinin and VOsil on the reduction in the concentration of 1,1-diphenyl-2-picrylhydrazyl radical. Values are expressed as the mean \pm the standard error of the mean (SEM) of at least three independent experiments 


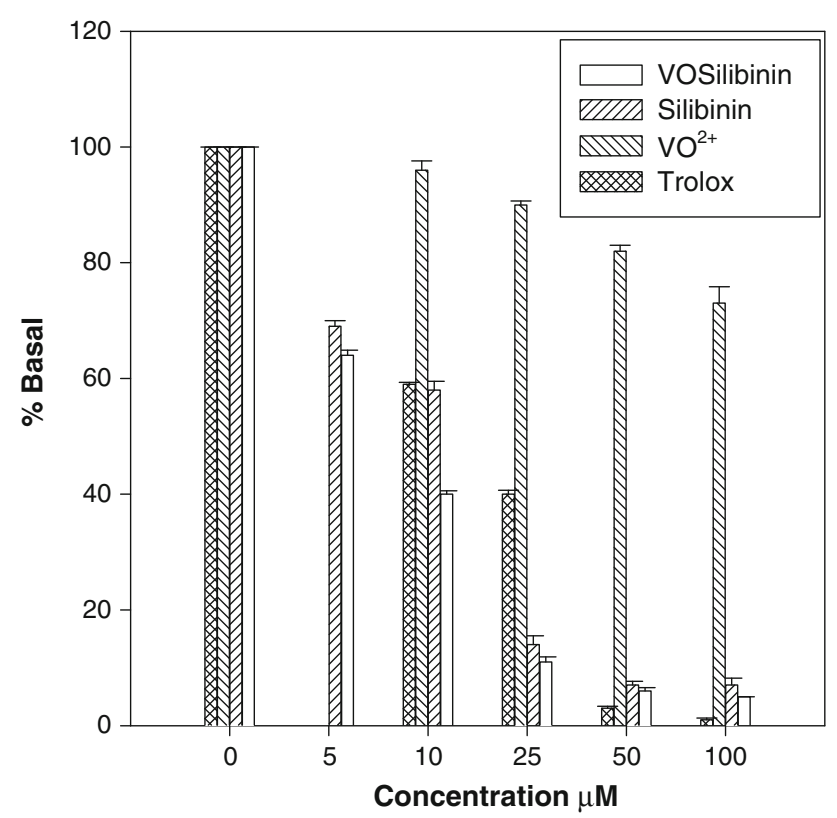

Fig. 8 Total antioxidant activity measured as the reduction of the concentration of 2,2'-azinobis(3-ethylbenzothiazoline-6-sulfonic acid) diammonium salt radical cation caused by the addition of silibinin, VOsil, and Trolox. Values are expressed as the mean \pm SEM of at least three independent experiments

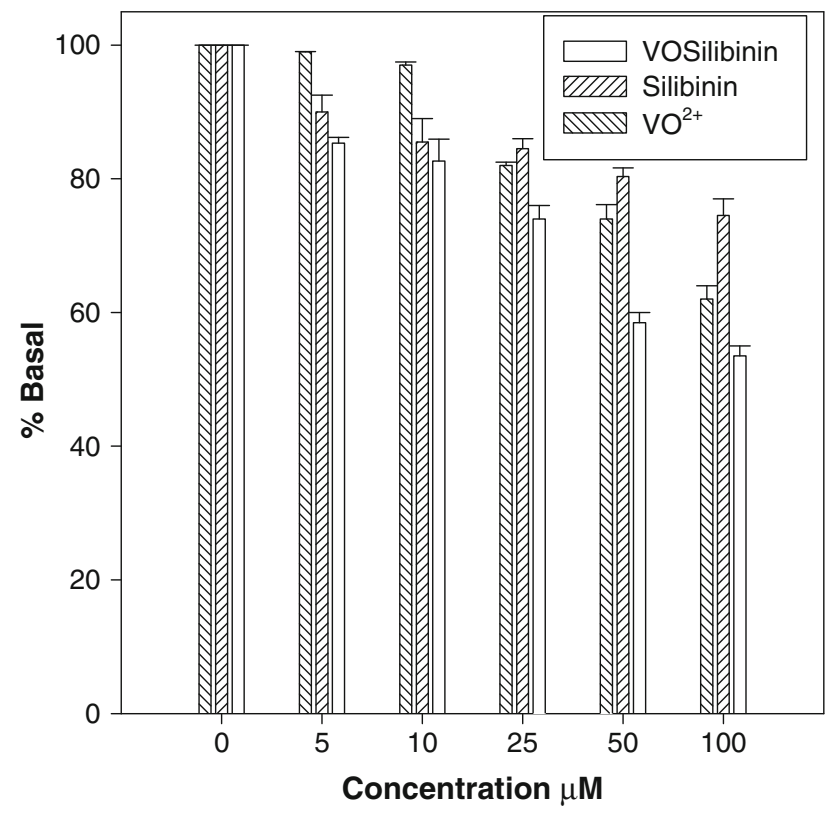

Fig. 9 Effect of $\mathrm{V}^{\mathrm{IV}} \mathrm{O}(\mathrm{II})$, silibinin, and VOsil on the extent of deoxyribose degradation by hydroxyl radical, measured with the thiobarbituric acid method. The values are expressed as the mean \pm SEM of at least three independent experiments

constituent of silymarin, our data agree with previous results on the effective radical cation scavenging activity of silymarin [39].

Figure 9 shows the effect of various concentrations of silibinin and VOsil on the hydroxyl-radical-induced degradation of deoxyribose, as detected by the thiobarbituric acid assay.

The $\mathrm{Fe}(\mathrm{III}) /$ ascorbate $/ \mathrm{H}_{2} \mathrm{O}_{2}$ system was used to produce hydroxyl radicals. Both silibinin and VOsil inhibited deoxyribose degradation in a dose-response manner, with $24 \%$ inhibition for $100 \mu \mathrm{M}$ silibinin and $45 \%$ inhibition for VOsil at the same concentration.

During the ORAC assay, the decrease in fluorescein intensity was followed to monitor the decay of the fluorescence curve to determine the antioxidant activities against peroxyl radicals. A typical ORAC fluorescein decay curve for Trolox calibrator over a range of Trolox standard concentrations is presented in Fig. 10. A calibration curve was obtained by plotting the area under the curve (AUC) (AUC Trolox minus AUC blank) against Trolox concentrations in the $0-100 \mu \mathrm{M}$ range. The experimental equation of the calibration curve was

$y=0.1907 x-0.8865$,

with a good correlation coefficient $\left(r^{2}=0.996\right)$. The relative ORAC value (Trolox equivalents) was calculated as

relative ORAC value $=[($ AUC sample - AUC blank $) /$

(AUC Trolox - AUC blank)]

$\times$ (molarity of Trolox/molarity of sample).

The experimental relative ORAC fluorescein values were 11.90 for VOsil and 5.03 for silibinin. These substances are better peroxide scavenger agents than quercetin (relative ORAC fluorescein value, 3.29) [40].

The redox reactivity of phenolic compounds can follow two different chemical pathways: hydrogen atom transfer mechanism or electron transfer mechanism [41]. It has previously been determined that silibinin exhibits only little radical scavenging capacity compared with other

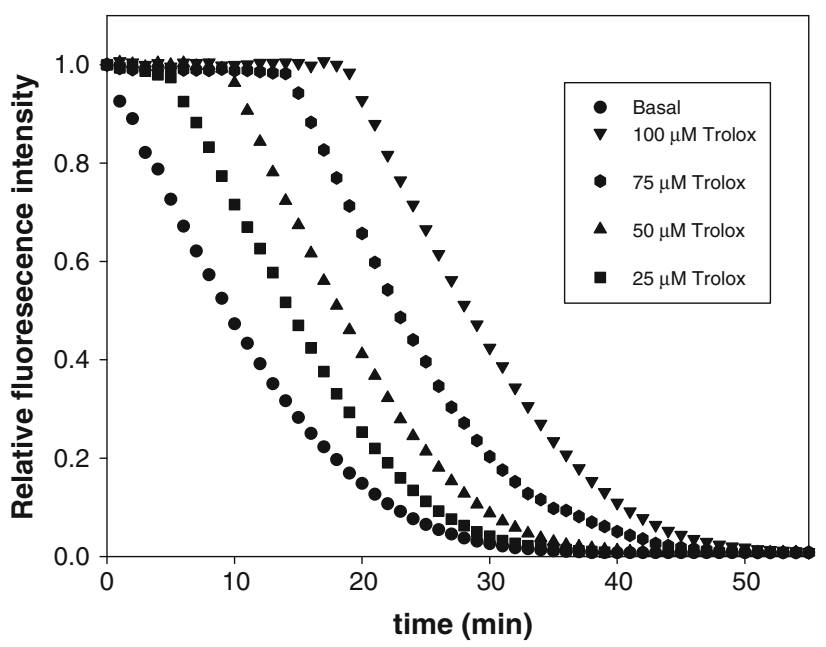

Fig. 10 Effect of the concentration of Trolox standard on the Trolox calibrator decay curve measured by changes in fluorescein intensity from 0 to $50 \mathrm{~min}$ 
flavonoids [42]. Besides, the free radical scavenging capacity of flavonolignans with the 2,3-double bond (dehydrosilibinin) was much higher than for silibinin. Dehydrosilibinin has a lower ionization potential energy than silibinin, and theoretical calculations indicated that the electron transfer mechanism was a thermodynamically unfavorable event for those compounds. Compounds were considered to be valuable antioxidant agents when the halfwave anodic potential values are lower than $200 \mathrm{mV}$. Silibinin and the methylated compounds exhibited one peak ranging from 542 to $572 \mathrm{mV}$ [43]. The redox behavior of flavonolignans can be divided into two parts: one attributed to the flavonoid moiety and the other attributed to the E-ring. The additive effect must be attributed to the weak electronic coupling between the two parts of the molecule. Silibinic acid, in which the primary alcohol group is replaced by a carboxylic acid, had only half of the antioxidative activity of silibinin, although its water solubility was improved 10 times [34]. The primary alcoholic group at C-23 was the most reactive under glycosylation conditions, affording high yields of the glycosides. Glycosylation of silibinin at C-23 caused better water solubility and an increase in the hepatoprotectivity behavior in comparison with silibinin $[43,44]$. The antioxidant properties of silibinin upon coordination were then improved for all the radicals tested and it can be assumed that the effect of coordination to a metal proceeded in a similar way as glycosylation. The delocalization of the electronic structure of oxovanadium(IV) with ring $\mathrm{A}$ or ring $\mathrm{C}$ may favor the electron-donating ability of the complex.

DNA cleavage activity of VOsil measured by AGE of plasmid DNA

It has been reported that the flavonoid quercetin binds to calf thymus DNA by electrostatic attraction and does not cleave this kind of nucleic acid [35]. However, its europium complex binds to DNA by both intercalation and electrostatic attraction. In the present case, and after digestion with the metal complex, plasmid DNA may retain its original supercoiled form, suffer single-strand cleavage, producing an open circular form, also named nicked form, or suffer double-strand cleavage, producing linear DNA. The appearance of the AGE bands corresponding to each form of DNA and their relative intensities shows the extent of DNA degradation. Digestion of plasmid DNA with VOsil under various conditions revealed this complex has no significant nuclease activity. This may be inferred from observation of the gels in Figs. S1 and S2, where the relative intensity of the bands of the supercoiled and nicked forms is unchanged on increasing the concentration of complex and on the addition of activating agents.
The complex concentration was varied from 6 to $50 \mu \mathrm{M}$, corresponding to a metal-to-bp ratio of $0.2-3.3$. The ligand silibinin was also tested (at $100 \mu \mathrm{M}$ ), and also showed no nuclease activity by itself. In similar conditions, complexes such as $\mathrm{V}^{\mathrm{IV}} \mathrm{O}(\mathrm{acac})_{2}$ are quite efficient nucleases, linearizing DNA at concentrations as low as $10 \mu \mathrm{M}[45,46]$. Samples digested with $50 \mu \mathrm{M} \mathrm{V} \mathrm{V}^{\mathrm{IV}} \mathrm{O}$ (acac) $)_{2}$ were added to each gel for comparison, and we observed a clear decrease in the intensity of the band of the supercoiled form, an increase in the intensity of the band of the nicked form, and the appearance of a band originating from the linear form, corresponding to extensive DNA cleavage and linearization.

All digestions were performed under relatively mild conditions: $1 \mathrm{~h}$ at $37{ }^{\circ} \mathrm{C}$, solutions buffered at $\mathrm{pH}$ 7.0. Two different $\mathrm{pH}$ buffers were tested: an organic buffer, MOPS, and phosphate, an inorganic buffer which may reflect better the biological conditions but which may in some cases affect the complex equilibria of oxovanadium, and has been reported to affect the nuclease efficiency of vanadium complexes such as $\mathrm{V}^{\mathrm{IV}} \mathrm{O}(\text { acac })_{2}$ derivatives [46]. MPA was added as a reducing activating agent, and oxone was added as an oxidizing activating agent. These agents simulate reducing conditions as may be found inside biological cells, and oxidizing conditions as may be found in blood or in contact with the air. The absence of nuclease activity of VOsil, even in the presence of these activating agents, shows it is a relatively harmless complex from the perspective of DNA cleavage.

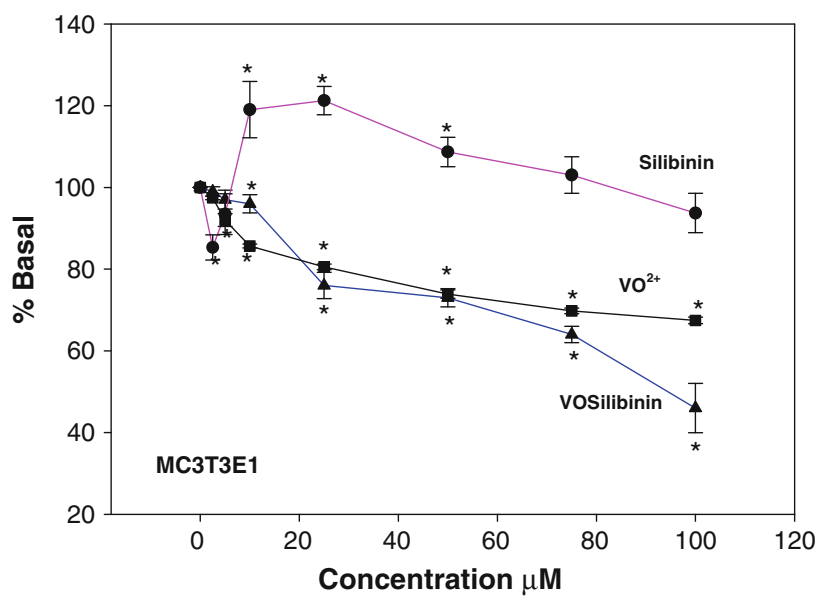

Fig. 11 Effects of silibinin (circles), VOsil (triangles), and $\mathrm{V}^{\mathrm{IV}} \mathrm{O}(\mathrm{II})$ (squares) on MC3T3E1 osteoblast-like cell proliferation. Cells were incubated in serum-free Dulbecco's modified Eagle's medium (DMEM) alone (basal) or with different concentrations of the compounds at $37{ }^{\circ} \mathrm{C}$ for $24 \mathrm{~h}$. The results are expressed as the percentage of the basal level and represent the mean $\pm \operatorname{SEM}(n=9)$. Asterisks significant values in comparison with the basal level $(P<0.01)$ 


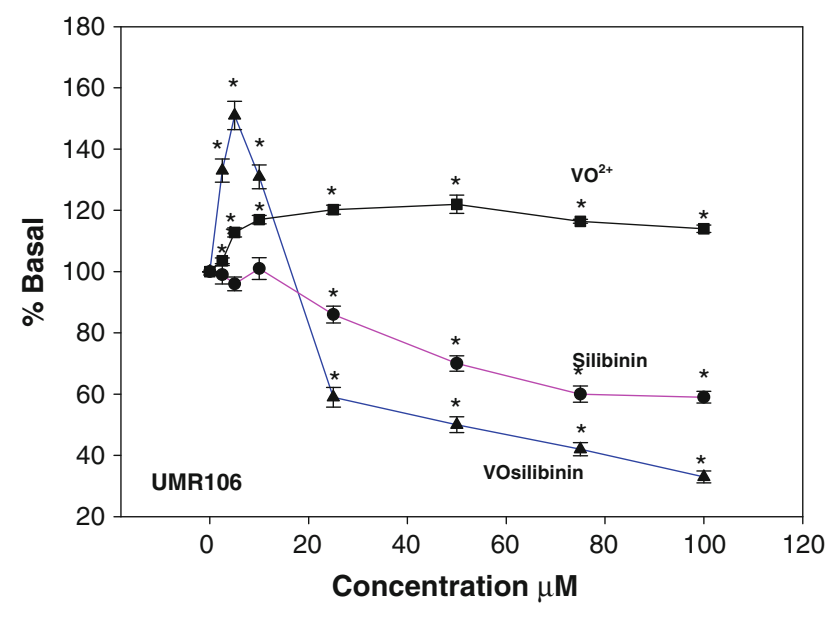

Fig. 12 Effects of silibinin (circles), VOsil (triangles), and $\mathrm{V}^{\mathrm{IV}} \mathrm{O}(\mathrm{II})$ (squares) on UMR106 osteoblast-like cell proliferation. Cells were incubated in serum-free DMEM alone (basal) or with different concentrations of the compounds at $37{ }^{\circ} \mathrm{C}$ for $24 \mathrm{~h}$. The results are expressed as a percentage of the basal level and represent the mean \pm SEM $(n=9)$. Asterisks significant values in comparison with the basal level $(P<0.01)$

\section{Cellular proliferation}

Cell proliferation was estimated through the crystal violet assay on two osteoblast-like cell lines in culture: UMR106, derived from a rat osteosarcoma and MC3T3E1, derived from mouse calvaria. The effects of the silibinin, $\mathrm{V}^{\mathrm{IV}} \mathrm{O}(\mathrm{II})$, and VOsil were investigated (Figs. 11, 12).

The results showed that the ligand acted as an antitumoral compound, causing a proliferative effect up to $50 \mu \mathrm{M}$ concentration on the normal cells and inhibiting the proliferation of the tumoral cells by up to $40 \%$ at $100 \mu \mathrm{M}$ in a dose-response manner. In contrast, oxovanadium(IV) produced the opposite effect: a slight proliferation on the tumoral cells and a deleterious behavior for the normal osteoblasts, inhibiting cell proliferation by approximately $30 \%$ at $100 \mu \mathrm{M}$. On the other hand, for the complex a similar injurious action as for oxovanadium(IV) on normal osteoblasts could be observed, with values of approximately $50 \%$ at $100 \mu \mathrm{M}$. However, the complex induced proliferation of the tumoral cells at low doses (up to $10 \mu \mathrm{M})$ and a cytotoxic effect at concentrations higher than $25 \mu \mathrm{M}$, with a deleterious action of $70 \%$ at $100 \mu \mathrm{M}$. Overall, these results indicate that the complex formation improved the action of the ligand in the UMR106 cell line.

\section{Intracellular ROS generation}

To confirm the possible role of oxidative stress in the silibinin- and VOsil-induced cytotoxicity in the UMR106 cell line, we studied the ROS formation measured by oxidation of DHR 123 to rhodamine (Figs. 13, 14) by fluorometry in both cell lines.

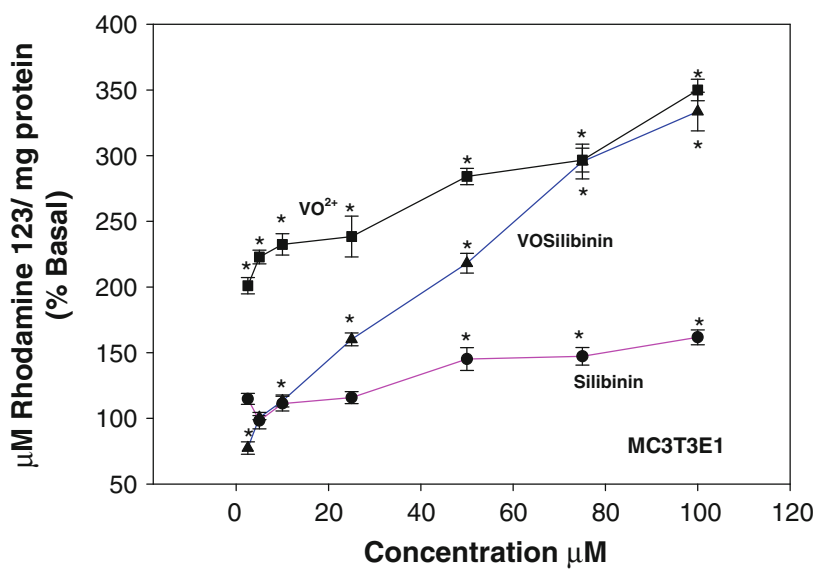

Fig. 13 Effects of silibinin (circles), VOsil (triangles), and $\mathrm{V}^{\mathrm{IV}} \mathrm{O}(\mathrm{II})$ (squares) on dihydrorhodamine 123 (DHR 123) oxidation to rhodamine 123. MC3T3E1 cells were incubated at $37{ }^{\circ} \mathrm{C}$ in the presence of $10 \mathrm{mM}$ DHR 123. The values are expressed as a percentage of the basal level for DHR 123 oxidation to rhodamine 123 and represent the mean \pm SEM $(n=6)$. Asterisks significant values in comparison with the basal level $(P<0.01)$

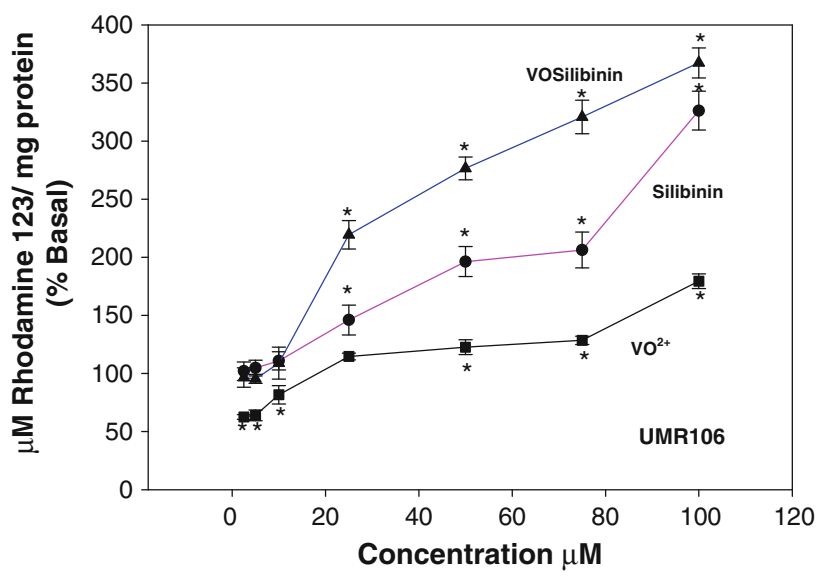

Fig. 14 Effects of silibinin (circles), VOsil (triangles), and $\mathrm{V}^{\mathrm{IV}} \mathrm{O}$ (II) (squares) on DHR 123 oxidation to rhodamine 123. UMR106 cells were incubated at $37{ }^{\circ} \mathrm{C}$ in the presence of $10 \mathrm{mM}$ DHR 123. The values are expressed as a percentage of the basal level for DHR 123 oxidation to rhodamine 123 and represent the mean $\pm \operatorname{SEM}(n=6)$. Asterisks significant values in comparison with the basal level $(P<0.01)$

As mentioned earlier, this probe is a nonfluorescent compound which can detect different ROS, particularly $\mathrm{H}_{2} \mathrm{O}_{2}$ [47]. The DHR probe has great affinity for the mitochondria and is oxidized to the fluorescent agent rhodamine 123 in the presence of oxidant agents.

The flavonoid silibinin produced increased quantities of ROS in a dose-dependent manner in the UMR106 cell line, with this effect being less significant in the case of the normal osteoblasts, in agreement with the respective inhibitory and proliferative effects observed in the proliferation assays. On the other hand, $\mathrm{V}^{\mathrm{IV}} \mathrm{O}(\mathrm{II})$ caused a slight 
dose-response increase in the ROS level in the tumoral cells, in parallel with its proliferative action, and in the case of the nontransformed osteoblasts oxovanadium(IV) generated a higher level of ROS and had a deleterious effect on cell proliferation. The comparatively higher ROS levels produced by VOsil in the tumoral line (approximately $370 \%$ of the basal level at $100 \mu \mathrm{M}$ ) in comparison with the effect in the normal line (approximately $320 \%$ of the basal level at $100 \mu \mathrm{M}$ ) could be related to its greater deleterious effect on the proliferation in the UMR106 cell line. Interestingly, the proliferative effect of VOsil in the tumoral cells up to a concentration of $10 \mu \mathrm{M}$ could be connected to the depletion of ROS generation at lower concentrations. In all the compounds tested, the induced increment of oxidative stress correlated quite well with the inhibition of cell proliferation in both cell lines. Superoxide radicals were not detected by the DHR 123 probe, but it was determined that VOsil is a very important superoxide scavenger (see Fig. 6). However, the antioxidant effect against hydroxyl radicals was less significant. Thus, the probable mechanism involved in the deleterious action of the complex may be related to the effect of the free radicals that were detected by this method, such as hydroxyl radicals.

\section{Reversibility assays}

In general, cell injury is usually reversible to a certain point, after which irreversible cell injury and death occur. Whether a specific stress causes irreversible or reversible cell injury depends on the severity of the insult and on

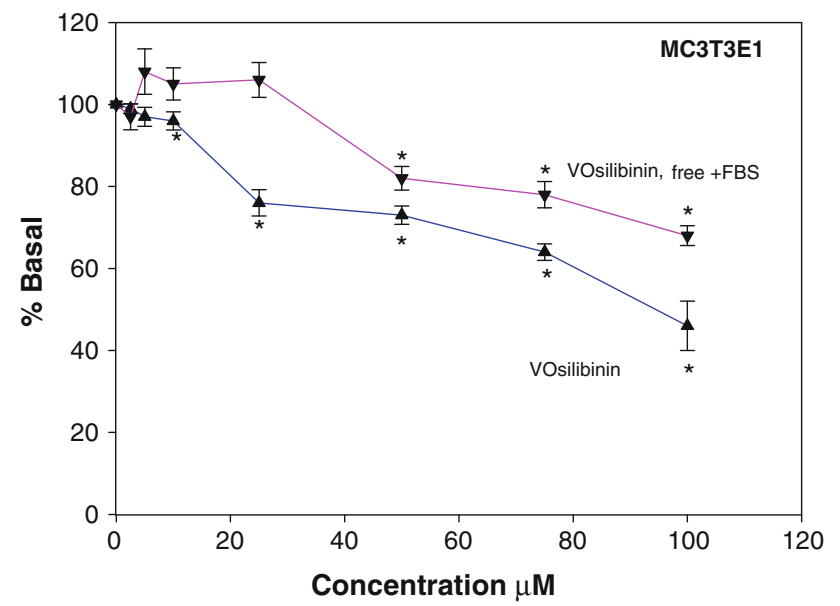

Fig. 15 Cellular proliferation assays and reversibility measurements (MC3T3E1). Upright triangles cells incubated with VOsil for $24 \mathrm{~h}$, under the same conditions as for Fig. 11. Inverted triangles the same cells with removal of the oxovanadium(IV) compound, treated with DMEM supplemented with fetal bovine serum $(F B S)$, and incubated for an additional $24 \mathrm{~h}$ with DMEM plus FBS at $37^{\circ} \mathrm{C}$. The results are expressed as a percentage of the basal level and represent the mean \pm SEM $(n=9)$. Asterisks significant values in comparison with the basal level $(P<0.01)$

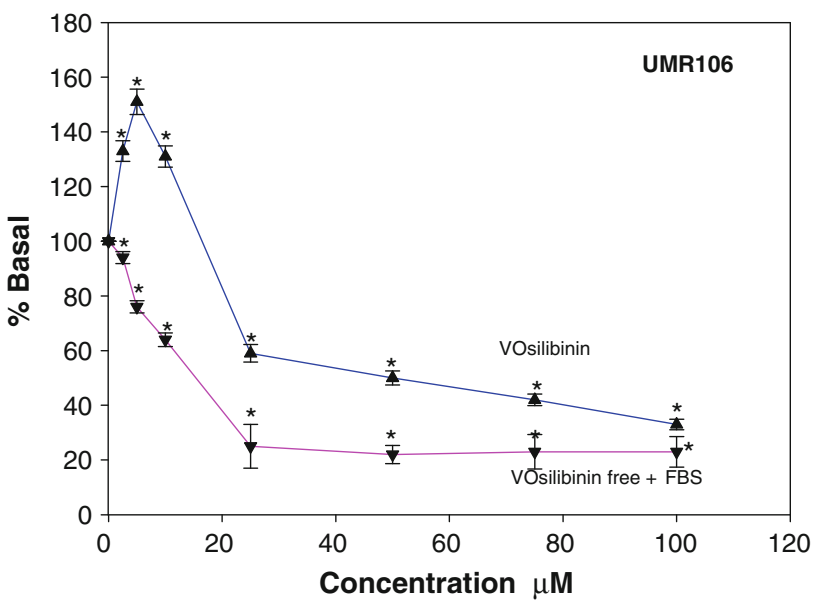

Fig. 16 Cellular proliferation assays and reversibility measurements (UMR106). Upright triangles cells incubated with VOsil for $24 \mathrm{~h}$, under the same conditions as for Fig. 12. Inverted triangles the same cells with removal of the oxovanadium(IV) compound, treated with DMEM supplemented with FBS, and incubated for an additional $24 \mathrm{~h}$ with DMEM plus FBS at $37{ }^{\circ} \mathrm{C}$. The results are expressed as a percentage of the basal level and represent the mean $\pm \operatorname{SEM}(n=9)$. Asterisks significant values in comparison with the basal level $(P<0.01)$

variables such as nutritional status and regenerative capacity. It can be observed from Figs. 15 and 16 that the damage caused by the complex did not revert and, on the contrary, it became worse, indicating that the alterations were irreversible in the case of the tumoral cells.

This effect was contrary to the behavior for the normal cell lines. The deleterious effect on the proliferation of this cell line at lower concentrations (between 10 and $25 \mu \mathrm{M}$ ) totally reverted when the complex was eliminated from the culture and the cells were allowed to grow for $24 \mathrm{~h}$. At higher concentrations, the deleterious effect partially reverted in the absence of the complex. We suggest that the VOsil complex generated ROS that influence the proliferation of the normal cells but the effect was reversible an the former condition could be restored by elimination of the ROS source. On the other hand, the damage produced by the ROS generated by VOsil in the tumoral cells became irreversible. The mechanisms of cell injury can produce sublethal and reversible cellular damage or lead to irreversible injury with cell death. Cell death can involve one of two mechanisms: apoptosis or necroses, which occur in irreversibly damaged cells. We suppose that in the case of the damaged tumoral cells the injury produced by the complex was irreversible and so it could not be reversed when the complex was removed.

\section{Cell morphology}

The normal MC3T3E1 osteoblastic cells displayed fibroblastic characteristics with slender lamellar expansions that 
Fig. 17 Effect on cell morphology of the treatment of osteoblatic cell lines (MC3T3E1) with VOsil. Osteoblasts were incubated for $24 \mathrm{~h}$ without drug addition (basal) and with VOsil (50 and $100 \mu \mathrm{M})(\times 40)$

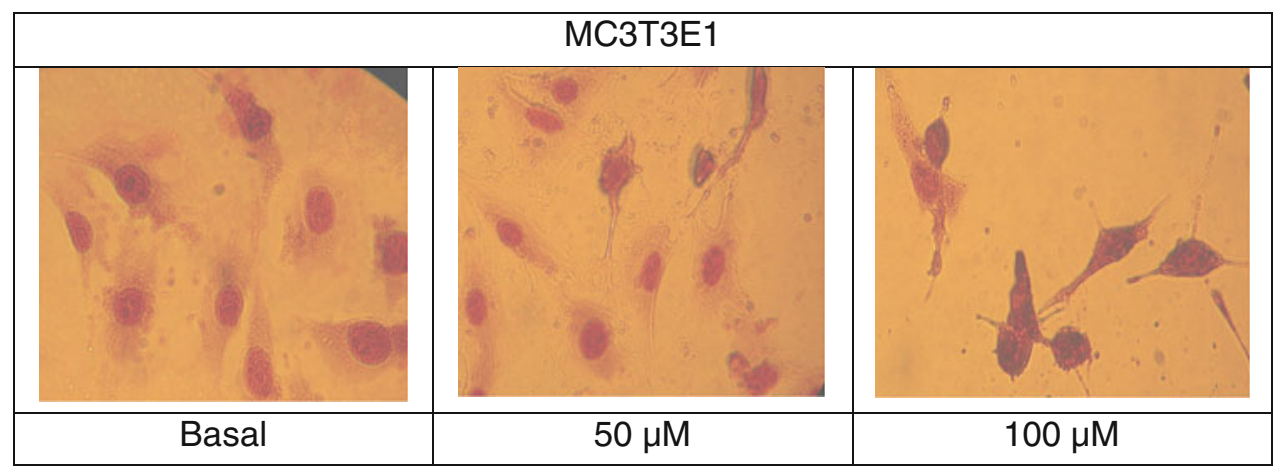

join each cell with its neighboring cell (Fig. 17). The nuclei were rounded oval with moderately thick chromatin granules and visible nucleoles. Preparations with $50 \mu \mathrm{M}$ VOsil showed a gradual loss of connections and an increase in cytoplasm condensation. Besides, a sticking decrease in the cell number/field could be observed since cells died and detached from the monolayers. At $100 \mu \mathrm{M}$ a more marked effect was observed. The cytoplasm had disappeared and the nuclei became spindlelike and condensed.

The tumoral cells (UMR106) under basal conditions (medium alone) displayed a polygonal morphology with well-stained nuclei and cytoplasm with processes connecting neighboring cells (Fig. 18). After the treatment with $50 \mu \mathrm{M}$ VOsil, a slight decrease in the number of cells could be observed. The differences from the observations in the basal conditions were insignificant. The treatment with $100 \mu \mathrm{M}$ VOsil produced a different morphology of the nuclei and less defined borders with loss of cytoplasm. A decrease in the number of cells/field was observed. The nuclei displayed dense chromatin granules and many membrane blebs, indicating an active apoptosis process.

The best antioxidants versus the best antitumorals

The antioxidant flavonoids can delay or inhibit oxidation of lipids and other molecules by inhibiting the initiation or propagation of oxidizing chain reactions [48]. It is not well established how flavonoids exert their beneficial action and it seems that the best antioxidant flavonoids, such as quercetin, are not necessarily the ones with the best bioavailability, stability, and biologic effect. Direct correlations between the antioxidant capacity and the antitumor potential against cancer cell lines were previously established [49, 50]. Besides, some correlations have been obtained between the lack of cytotoxic effects of some flavonoids [51] and the reduction of induced cytotoxicity in cells with their antioxidant properties [52]. It has also been suggested that the number of $\mathrm{OH}$ and substituted $\mathrm{OH}$ groups, such as $\mathrm{OCH}_{3}$ groups, plays an important role of in cytotoxicity [53]. Nevertheless, it may be that the inherent antioxidant activity of flavonoids and other polyphenols, which was for a long time believed to be directly correlated with their health effects, in particular with prevention, delay, or helping in the cure of cancer, has no direct correlation with their final biological effects. Thus, although measuring antioxidant activities of natural products in vitro or by methods based on chemical quenching of standard oxidants is still valuable as a quick reference method to determine the presence of polyphenols, other tests involving biological measurements, such as cellular proliferation, must be used to understand the final biological responses.

The antioxidant activities of selected and structurally related flavonoids and their effects in two osteoblastic cell lines in culture (one normal and the other tumoral) are compared in Table 2 and Fig. 19, respectively.

In recent years, the anticancer properties of vanadium compounds have been noticed, but the underlying mechanisms are not well understood. Oxovanadium(IV) cation
Fig. 18 Effect on cell morphology of the treatment of osteoblatic cell lines (UMR106) with VOsil. Osteoblasts were incubated for $24 \mathrm{~h}$ without drug addition (basal) and with VOsil $(50$ and $100 \mu \mathrm{M})(\times 40)$

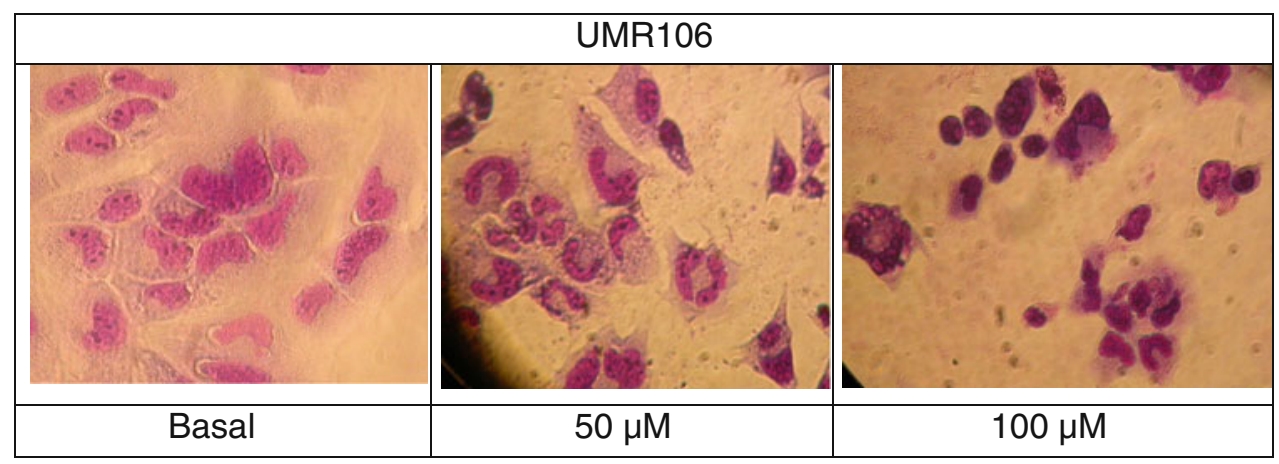


Table 2 Comparison of the scavenger effects of selected flavonoids and their oxovanadium(IV) complexes [31, 36]

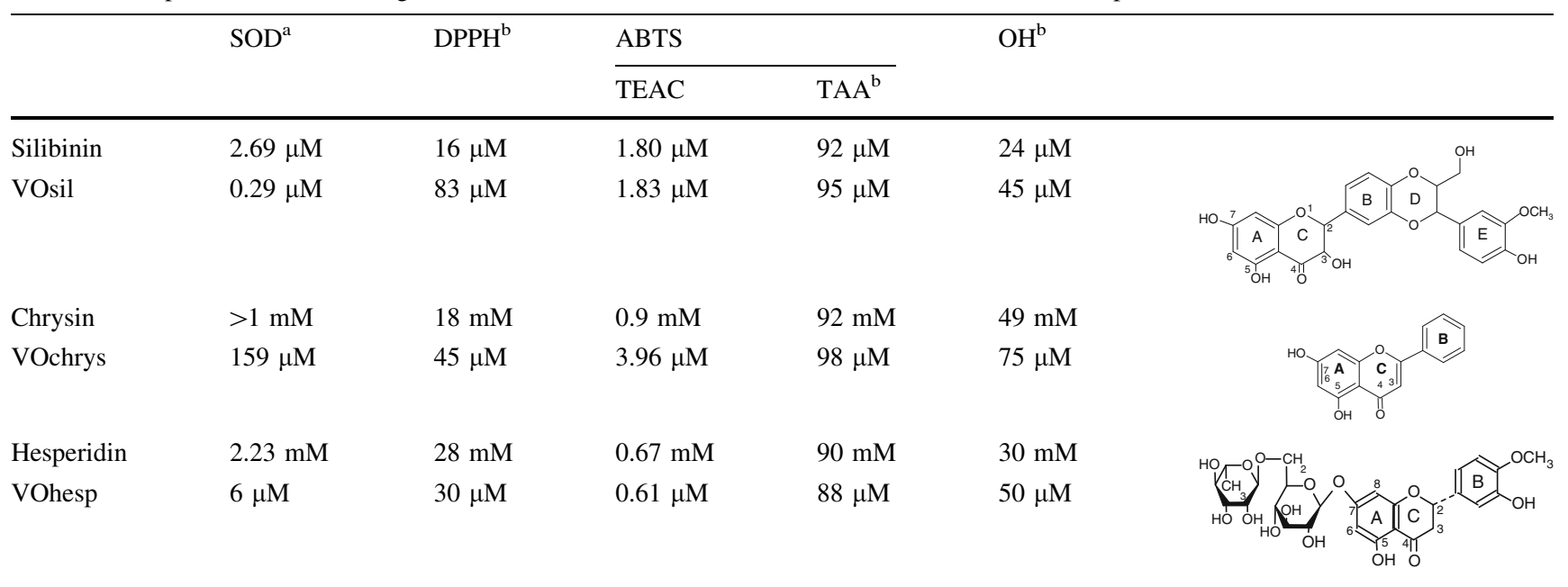

SOD superoxide dismutase, DPPH 1,1-diphenyl-2-picrylhydrazyl, ABTS 2,2'-azinobis(3-ethyl-benzothiazoline-6-sulfonic acid) diammonium salt, TEAC Trolox-equivalent antioxidant coefficient, TAA total antioxidant activity, VOchrys $\left[\mathrm{VO}(\mathrm{chrysin})_{2} \text { EtOH }\right]_{2}, \quad$ VOhesp $\left[\mathrm{VO}(\mathrm{Hesp})(\mathrm{OH})_{3}\right] \mathrm{Na}_{4} \cdot 3 \mathrm{H}_{2} \mathrm{O}$

${ }^{a}$ SOD native enzyme, $0.21 \mu \mathrm{M}$

b Total basal inhibition at $100 \mu \mathrm{M}$

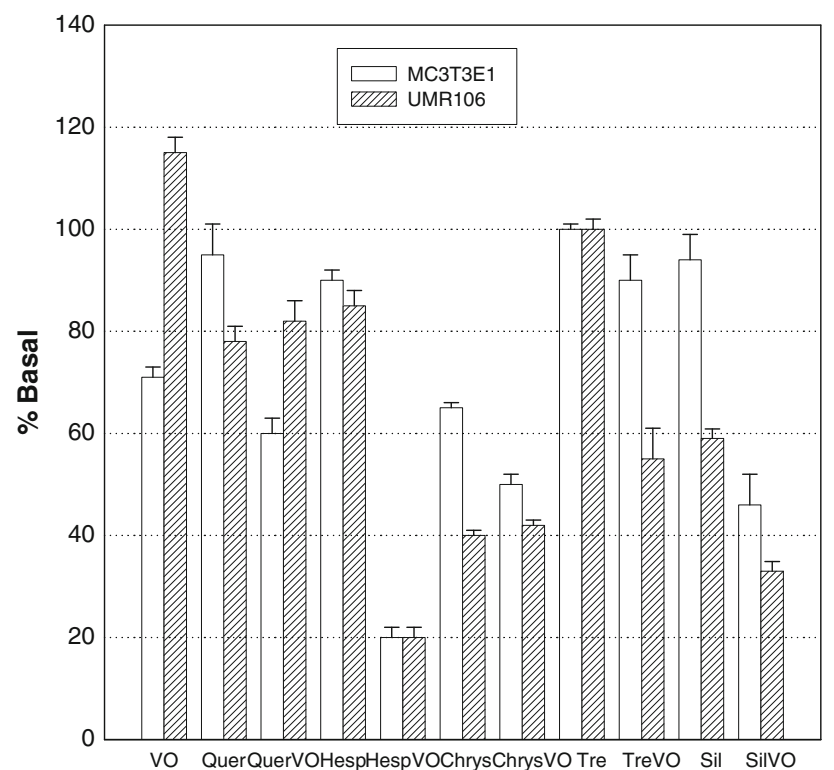

Fig. 19 Effects of $\mathrm{V}^{\mathrm{IV}} \mathrm{O}(\mathrm{II})$, quercetin (quer), hesperidin (hesp), chrysin (chrys), trehalose (tre), silibinin (sil) and their oxovanadium(IV) complexes $(100 \mu \mathrm{M})$ on MC3T3E1 and UMR106 osteoblast-like cell proliferation

favored ROS generation in normal osteoblasts. On the contrary, in the basal state of the UMR106 cell line, there exist a high content of ROS and, by addition of oxovanadium(IV), a little generation of ROS (relative to basal) is detected. The cytotoxic effects of the metal cation are demonstrated by the proliferative effect exerted on the tumoral cells. Therapeutic applications of vanadium compounds with antioxidants in order to reduce their toxicity in normal human cells without affecting their antitumoral action in cancer cells have been established [54]. Instead of supplying each compound separately, we have synthesized coordination compounds between $\mathrm{V}^{\mathrm{IV}} \mathrm{O}(\mathrm{II})$ cation and some flavonoids, and studied their biological behavior.

In the literature, the structure-activity relation was usually referred to the effect of the antioxidants in the scavenger action of the initiator of $\mathrm{ABTS}^{+}$, the peroxodisulfate anion, and the comparison with the effect of Trolox gave the Trolox-equivalent activity (TEAC). Taking into account this property, our own data are in agreement with published results [15], with silibinin being the best antioxidant, followed by chrysin and hesperidin, in accordance with their structures (presence of 3-OH and 7-OH, presence of 2,3-double bond and 7-OH, none of them, respectively) $[27,33,37]$. But when the antioxidant activity was determined by the capacity to scavenge other radicals these results did not correlate with other experimental results [55]. It is shown in Table 2 that hesperidin was a better scavenger for DPPH. and that chrysin was better for the hydroxyl radical.

Moreover, upon coordination, the TEAC measurements indicated an improvement of the antioxidant activity only for chrysin. The other scavenger capacities (SOD, DPPH, and $\mathrm{OH}$ ) were improved by the interaction of the three flavonoids with the metal, and peroxyl radical scavenger power was greater for VOsil than for silibinin.

In conclusion, it can be determined that upon complexation: 
- The antioxidant capacity of the selected flavonoids against some ROS was improved.

- The bioavailability of VOsil was enhanced (the complex dissolved in water at low concentrations).

From Fig. 19 (at $100 \mu \mathrm{M}$ concentration of all compounds) it can be seen that silibinin did not exert any toxic effect on normal osteoblasts (like quercetin and hesperidin) but chrysin produced a great inhibition of proliferation. The ROS generation was measured only for chrysin [33] and silibinin. Silibinin did not produce ROS in the MC3T3E1 cell line and the production of ROS by chrysin is 3 times the basal level, with more evident toxicity. In the tumoral cell line, both flavonoids exerted toxic effects but the most pronounced cytotoxicity was again observed for chrysin owing to its higher production of ROS.

On the other hand (see Fig. 19), although it seems contradictory, in most cases the flavonoid- $\mathrm{V}^{\mathrm{IV}} \mathrm{O}(\mathrm{II})$ complexes produced improvement of the antioxidant and antitumoral effects of the separate compounds [27, 33, 37]. For the complexes tested, the most cytotoxic oxovanadium(IV) complex for the tumoral cell line is [ $\mathrm{VO}(\mathrm{Hesp})$ $\left.(\mathrm{OH})_{3}\right] \mathrm{Na}_{4} \cdot 3 \mathrm{H}_{2} \mathrm{O}$ (VOhesp) (good superoxide and hydroxyl radical scavenger agent), followed by VOsil and $\left[\mathrm{VO}(\text { chrysin })_{2} \mathrm{EtOH}\right]_{2}$ (VOchrys), in accordance with their ROS production behavior (measured for the latter two complexes).

\section{Conclusions}

In conclusion, the deleterious action of these compounds in the cells is most probably due to their capacity to generate ROS in situ, and not because of their antioxidant capacities measured in in vitro experiments.

In summary, the chemopreventive effects of flavonoids seem to be result from their ability to scavenge ROS, but the importance of the prooxidant effect of flavonoids for their anticancer effects [56-61] together with other mechanisms concerning cellular signal transduction pathways may also be relevant. Furthermore, it was demonstrated that silibinin and chrysin (data not published) and their oxovanadium(IV) complexes did not show linearizing or cleavage activities in plasmid DNA pA1.

Besides, among the flavonoids studied it has been found that the best candidates as antitumoral agents are silibinin and quercetin. Both flavonoids behaved as $\mathrm{Na}_{6}\left[\mathrm{VO}(\mathrm{Tre})_{2}\right] \cdot 4 \mathrm{H}_{2} \mathrm{O}$ (VOtre) [62] and did not exert any effect on the proliferation of the normal cells but produced a deleterious effect on the tumoral osteoblasts. For this reason we included a comparison of the behavior in both cell lines (normal and tumoral), which is of great relevance and is not usually discussed in the literature. Only in the case of quercetin was the antitumoral effect of the complex unsuccessful, because $\left[\mathrm{VO}(\mathrm{Quer})_{2}\right.$. $\mathrm{EtOH}]_{\mathrm{n}}$ (VOquer) exerted a more deleterious effect on normal cells than on tumoral cells (the antioxidant properties of the complex were not measured).

Acknowledgments This work was supported by UNLP, CONICET (PIP1125), ANPCyT (PICT 2008-2218), and CICPBA. E.G.F. and S.B.E. are members of the Carrera del Investigador CONICET. P.A.M.W. is a member of the Carrera del Investigador CICPBA, Argentina. L.N. holds a fellowship from CONICET.

\section{References}

1. Gazák R, Walterová D, Kren V (2007) Curr Med Chem 14:315-338

2. Svagera Z, Skottová N, Vána P, Vecera R, Urbánek K, Belejová M, Kosina P, Simánek V (2003) Phytother Res 17:524-530

3. Varga Z, Czompa A, Kakuk G, Antus A (2001) Phytother Res 15:608-612

4. Singh RP, Agarwal R (2004) Curr Cancer Drug Targets 4:1-11

5. Mokhtari MJ, Motamed N, Shokrgozar MA (2008) Cell Biol Int 32:888-892

6. Bhatia N, Zhao J, Wolf DM, Agarwala R (1999) Cancer Lett 147:77-84

7. Hogan FS, Krishnegowda NK, Mikhailova M, Kahlenberg MS (2007) J Surg Res 143:58-65

8. Mascher H, Kikuta C, Weyhemmeyer R (1993) J Liq Chromatogr 16:2777-2789

9. Arcari M, Brambilla A, Brandt A, Caponi R, Corsi G, Di Rella M, Solinas F (1992) Boll Chim Farm 131:205-209

10. Yang LX, Huang KX, Li HB, Gong JX, Wang F, Feng YB, Tao QF, Wu YH, Li XK, Wu XM, Zeng S, Spencer S, Zhao Y, Qu J (2009) J Med Chem 52:7732-7752

11. Evangelou AM (2002) Crit Rev Oncol Hematol 42:249-265

12. Etcheverry SB, Williams PAM (2009) New developments in medicinal chemistry. In: Ortega MP, Gil IC (eds) Medicinal chemistry of copper and vanadium bioactive compounds. Nova Science, Hauppauge, pp 105-129

13. Onishi M (1988) Photometric determination of traces of metals, part II, 4th edn. Wiley, New York

14. Yamaguchi T, Takamura H, Matoba TC, Terao J (1998) Biosci Biotechnol Biochem 62:1201-1204

15. Re R, Pellegrini N, Proteggente A, Pannala A, Yang M, RiceEvans C (1999) Free Radic Biol Med 26:1231-1237

16. Gorinstein S, Moncheva S, Katrich E, Toledo F, Arancibia P, Goshev I, Trakhtenberg S (2003) Mar Pollut Bull 46:1317-1325

17. Kuo CC, Shih M, Kuo Y, Chiang W (2001) J Agric Food Chem 49:1564-1570

18. Halliwell B, Gutteridge JMC, Aruoma OI (1987) Anal Biochem $165: 215-219$

19. Zhong Z, Ji X, Xing R, Liu S, Guo Z, Chen X, Li P (2007) Bioorg Med Chem 15:3775-3782

20. Tijerina Sáenz A, Elisia I, Innis SM, Friel JK, Kitts DD (2009) J Food Compost Anal 22:694-698

21. Zulueta A, Esteve MJ, Frívola A (2009) Food Chem 114:310-316

22. Fisher MB, Thompson SJ, Ribeiro V, Lechner MC, Rettie A (1998) Arch Biochem Biophys 356:63-70

23. Cortizo AM, Etcheverry SB (1995) Mol Cell Biochem 145:97-102

24. Krejsa CM, Nadler SG, Esselstyn JM, Kavanagh TJ, Ledbetter JA, Schieven GL (1997) J Biol Chem 272:11541-11549 
25. Bradford M (1976) Anal Biochem 72:248-254

26. Sálice VC, Cortizo AM, Gómez Dumm CL, Etcheverry SB (1999) Mol Cell Biochem 198:119-128

27. Ferrer EG, Salinas MV, Correa MJ, Naso L, Barrio DA, Etcheverry SB, Lezama L, Rojo T, Williams PAM (2006) J Biol Inorg Chem 11:791-801

28. Levchenko LA, Kartsev VG, Sadkov AP, Shestakov AF, Shilova AK, Shilov AE (2007) Dokl Chem 412(2):35-37

29. Borsaria M, Gabbia C, Ghelfia F, Grandia R, Saladinia M, Severi S, Borell F (2001) J Inorg Biochem 85:123-129

30. Harris WR, Raymond KN (1979) J Am Chem Soc 101:6534-6541

31. Popescu CM, Singure G, Popescu MC, Vasile C, Argyropoulos DS, Willför S (2009) Carbohydr Polym 77:851-857

32. Chasteen ND (1981) In: Berliner LJ, Reuben J (eds) Biological magnetic resonance, vol 3. Plenum, New York

33. Naso L, Ferrer EG, Lezama L, Rojo T, Etcheverry SB, Williams PAM (2010) J Biol Inorg Chem 15:889-902

34. Meloun M, Burkonová D, Syrový T, Vrána A (2003) Anal Chim Acta 486:125-141

35. Kang J, Zhuo L, Lu X, Liu H, Zhang M, Wu H (2004) J Inorg Biochem 98:79-86

36. Gazák R, Svobodová A, Psotová J, Sedmera P, Prikrylová V, Walterová D, Kren V (2004) Bioorg Med Chem 12:5677-5687

37. Etcheverry SB, Ferrer EG, Naso L, Rivadeneira J, Salinas V, Williams PAM (2008) J Biol Inorg Chem 13:435-447

38. Okawa M, Kinjo J, Nohara T, Ono M (2001) Biol Pharm Bull 24:1202-1205

39. Köksal E, Gülcn 1, Beyza S, Sarikaya Ö, Bursal E (2009) J Enzyme Inhib Med Chem 24:395-405

40. Cao G, Sofic E, Prior RL (1997) Free Radic Biol Med 22:749-760

41. Trouillas P, Marsal P, Svobodová A, Vostálová J, Gazák R, Hrbác J, Sedmera P, Kren V, Lazzaroni R, Duroux JL, Walterová D (2008) J Phys Chem A 112:1054-1063

42. György I, Antus S, Földiak G (1992) Radiat Phys Chem 39:81-84

43. Kren V, Kubisch J, Sedmera P, Halada P, Prikrylová V, Jegorov A, Cvak L, Gebhardt R, Ulrichová H, Simánek V (1997) J Chem Soc Perkin Trans 1:2467-2474

44. Kren V, Ulrichová J, Kosina P, Stevenson D, Sedmera P, Prikrylová V, Halada P, Imánek VS (2000) Drug Met Dispos 28:1513-1517
45. Costa Pessoa J, Cavaco I, Correia I, Tomaz I, Adão P, Vale I, Ribeiro V, Castro MMCA, Geraldes CCFG (2007) In: Kustin K, Costa Pessoa J, Crans DC (eds) Vanadium: the versatile metal. ACS symposium series, vol 974. American Chemical Society, Washington, pp 340-351

46. Butenko N, Tomaz AI, Nouri O, Escribano E, Moreno V, Gama S, Ribeiro V, Telo JP, Costa Pessoa J, Cavaco I (2009) J Inorg Biochem 103:622-632

47. Capella MAM, Capella LS, Valente RC, Gefé M, Lopes AG (2007) Cell Biol Toxicol 23:413-420

48. Ferreira JFS, Luthria DL, Sasaki T, Heyerick A (2010) Molecules 15:3135-3170

49. Pittella UF, Dutra RC, Junior DD, Lopes MTP, Barbosa NR (2009) Int J Mol Sci 10:3713-3721

50. de Pohlit Almeida Telles P, Macari CN, Portela AM (2006) Acta Amazon 36:513-518

51. Sharma RJ, Chaphalkar SR, Adsool AD (2010) Int J Biotechnol 2:01-05

52. Moein S, Farzami B, Khaghani S, Moein MR, Larijani B (2007) DARU 15:83-88

53. Jeong JM, Kang SK, Lee IH, Lee JY, Jung H, Choi CH (2007) J Pharm Pharm Sci 10:537-546

54. Wang Q, Liu T, Fu Y, Wang K, Yang X (2010) J Biol Inorg Chem 15:1087-1097

55. Chen YT, Zheng RL, Jia ZJ, Ju Y (1990) Free Radic Biol Med 9:19-21

56. Wilms LC, Jos CS, Kleinjans EJC, Moonen J, Briede J (2008) Toxicol In Vitro 22:301-307

57. Sakao K, Fujii M, Hou DX (2009) Biosci Biotechnol Biochem 73:2048-2053

58. Galati G, O’Brien PJ (2004) Free Radic Biol Med 37:287-303

59. Srinivasan P, Vadhanam MV, Arif JM, Gupta RC (2002) Int J Oncol 20:983-986

60. Tobi SE, Gilbert M, Paul N, McMillan TJ (2002) Int J Cancer 102:439-444

61. Mladěnka P, Zatloukalová L, Filipský T, Hrdina R (2010) Free Radic Biol Med 49:963-975

62. Barrio DA, Williams PAM, Cortizo AM, Etcheverry SB (2003) J Biol Inorg Chem 8:459-468 